\title{
Control of hair follicle cell fate by underlying mesenchyme through a CSL-Wnt5a-FoxN1 regulatory axis
}

\author{
Bing Hu, ${ }_{1}^{1}$ Karine Lefort, ${ }^{1}$ Wenying Qiu, ${ }^{1}$ Bach-Cuc Nguyen, ${ }^{2}$ Renuga Devi Rajaram, ${ }^{3}$ Einar Castillo, ${ }^{1}$ \\ Fenglei He, ${ }^{4}$ Yiping Chen, ${ }^{4}$ Peter Angel, ${ }^{5}$ Cathrin Brisken, ${ }^{3}$ and G. Paolo Dotto ${ }^{1,2,6}$ \\ ${ }^{1}$ Department of Biochemistry, University of Lausanne, Epalinges CH-1066, Switzerland; ${ }^{2}$ Cutaneous Biology Research Center, \\ Massachusetts General Hospital, Charlestown, Massachusetts 02129, USA; ${ }^{3}$ Swiss Institute for Experimental Cancer Research, \\ Ecole Polytechnique Fédérale de Lausanne, Epalinges CH-1066, Switzerland; ${ }^{4}$ Department of Cell and Molecular Biology, Tulane \\ University, New Orleans, Louisiana 70118, USA; ${ }^{5}$ German Cancer Research Center, Heidelberg D-69120, Germany
}

\begin{abstract}
Epithelial-mesenchymal interactions are key to skin morphogenesis and homeostasis. We report that maintenance of the hair follicle keratinocyte cell fate is defective in mice with mesenchymal deletion of the CSL/RBP-JK gene, the effector of "canonical" Notch signaling. Hair follicle reconstitution assays demonstrate that this can be attributed to an intrinsic defect of dermal papilla cells. Similar consequences on hair follicle differentiation result from deletion of Wnt5a, a specific dermal papilla signature gene that we found to be under direct Notch/CSL control in these cells. Functional rescue experiments establish Wnt5a as an essential downstream mediator of Notch-CSL signaling, impinging on expression in the keratinocyte compartment of FoxN1, a gene with a key hair follicle regulatory function. Thus, Notch/CSL signaling plays a unique function in control of hair follicle differentiation by the underlying mesenchyme, with Wnt5a signaling and FoxN1 as mediators.
\end{abstract}

[Keywords: Notch; Wnt; ROR2; FoxN1; epithelial-mesenchymal interactions]

Supplemental material is available at http://www.genesdev.org.

Received November 18, 2009; revised version accepted June 8, 2010.

The skin provides a well-studied example of epithelial cell differentiation and morphogenesis (Botchkarev and Paus 2003). In the interfollicular epidermis, keratinocytes terminally differentiate along a single lineage, while in hair follicles they undergo a complex differentiation program that gives rise to several concentric layers of cells with separate fates. Hair follicle morphogenesis and cycling are critically dependent on an interplay between keratinocytes and cues originating from the underlying mesenchyme (Botchkarev and Paus 2003). Several key developmental pathways are involved in establishing and/or maintaining the hair follicle keratinocyte cell fate, in concert with keratinocyte-specific genes like FoxN1, a transcription factor whose mutation results in the nude (mouse, rat, or human) phenotype (Mecklenburg et al. 2005).

Notch signaling is an important form of cell-cell communication that plays a key role in control of cell fate, stem cell potential, and differentiation (Bray 2006; Hurlbut et al. 2007). The Notch gene family (Notch1, Notch2, Notch3, and Notch4) consists of evolutionarily conserved transmembrane receptors. Interactions with ligands of the

${ }^{6}$ Corresponding author.

E-MAIL paolo.dotto@unil.ch; FAX 41-21-692-5705.

Article is online at http://www.genesdev.org/cgi/doi/10.1101/gad.1886910.
Delta and Jagged families, present on the surface of neighboring cells, trigger proteolytic cleavage of these receptors with release of the intracellular region of Notch receptors (NICD). The best characterized "canonical" pathway of Notch activation involves translocation of NICD to the nucleus, where it associates with the DNAbinding protein RBP-Jк (CBF-1 or CSL), converting it from a repressor into an activator of transcription (Kopan and Ilagan 2009).

This pathway is highly context-dependent, and can exert opposite roles in growth/differentiation of different cell types, at different developmental stages, and/or under normal versus pathological conditions. While great attention has been paid to the role of Notch signaling in the epithelial compartment of the skin, for both interfollicular and hair follicle keratinocyte differentiation (Dotto 2008; Watt et al. 2008), a possible role of this pathway in the adjacent mesenchyme has not been investigated. However, an indication of Notch activity in both dermal fibroblasts and dermal papilla cells has been provided by the analysis of transgenic mice with a Notch-responsive GFP reporter, immunostaining for activated Notch1 and/ or expression of "canonical" Notch target genes of the Hes/HERP family (Okuyama et al. 2004; Estrach et al. 2006; Moriyama et al. 2006; Lee et al. 2007). We report 
Hu et al.

here that CSL/RBP-Jк, the effector of "canonical" Notch signaling, plays an as yet unsuspected role in control of hair follicle cell fate by the underlying mesenchyme. This is linked to a unique nonredundant function of a specific Wnt family member, Wnt5a, as a direct Notch/CSL target in dermal papilla cells, with FoxN1 as a downstream target in keratinocytes.

\section{Results}

Compromised hair follicle differentiation in mice with mesenchymal deletion of the RBP-Jк gene

Little is known about the function of Notch signaling in cells of the mesenchymal lineage. "Canonical" Notch signaling is critically dependent on the DNA-binding protein CSL/RBP-Jк (Bray 2006). To delete this gene specifically in the mesenchyme, transgenic mice with Cre expression driven by the promoter of the collagen type I ( $\alpha 2$ chain) gene (ColI-Cre) (Florin et al. 2004) were crossed with mice with the RBP-JK gene flanked by loxP sites (Han et al. 2002). Further crossing of mice into a
ROSA26R background confirmed that, as reported previously (Florin et al. 2004), Cre activity in the skin was confined to dermal papilla cells and dermal fibroblasts (Supplemental Fig. 1). Specificity of deletion of the RBP-JK gene in the mesenchymal compartment of the skin (dermal papilla cells and dermal fibroblasts) was further verified by physical separation of various skin components, followed by real-time PCR analysis of genomic DNA (Supplemental Fig. 2). Analysis of embryonic skin showed specific deletion of the RBP-Jк gene in the mesenchymal compartment as early as embryonic day 15.5 (E15.5) (data not shown).

Phenotypically, homozygous (ColI-Cre $\times$ RBP-Jא ${ }^{\text {loxP/loxP }}$ ) mice were recognizable after birth by their "kinky" tail and smaller size, with areas of decreased hair density (Fig. 1A). They also exhibited a skeletal phenotype that will be presented elsewhere. Histologically, hair follicles were structurally normal at birth (Supplemental Fig. 3), but, by 4-10 d, a significant percentage started to show structural alterations, with disrupted inner root sheath (IRS) and cuticle layer organization, followed by hair shaft/ cortex alteration and signs of cystic degeneration (Fig.
A

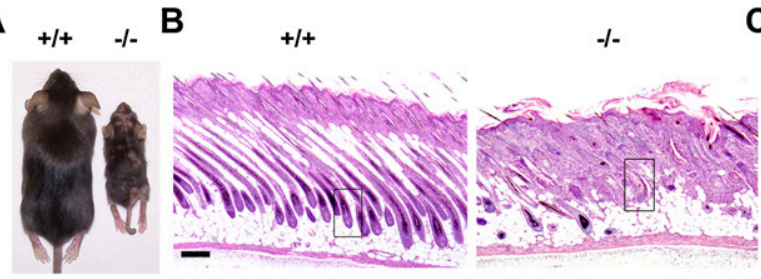

D

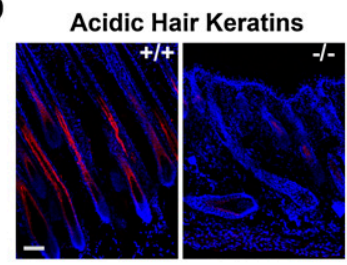

E

Cytokeratin 1

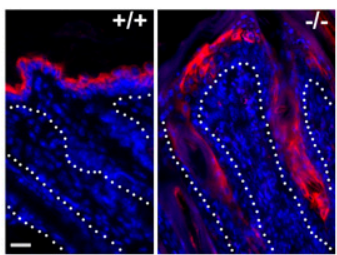

G Alkaline phosphatase $\mathbf{H}$

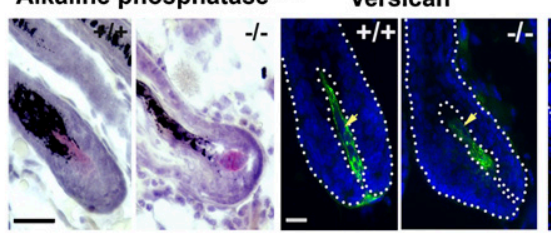

C

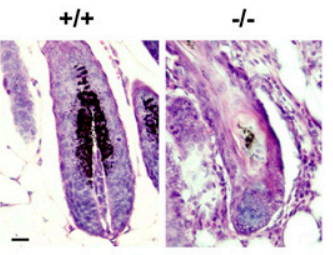

$\mathbf{F}$

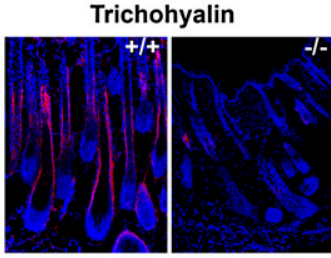

Cytokeratin 10
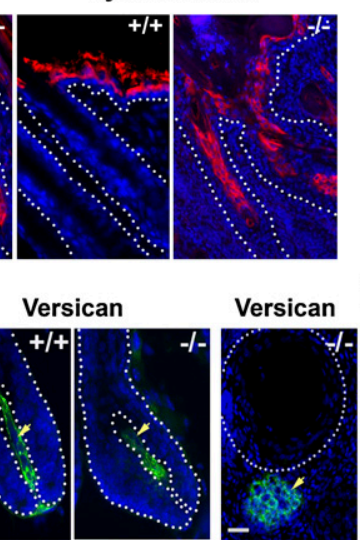

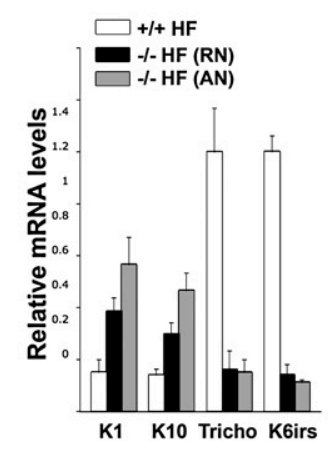

I

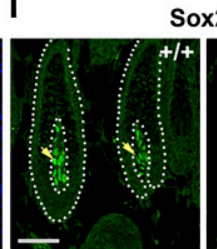

Sox2

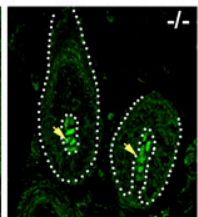

Figure 1. Defects in hair follicle differentiation in mice with mesenchymal deletion of the RBP-I $\kappa$ gene. $(A)$ Mice with the RBPJ $\kappa$ deletion $(-/-)$ and age-matched controls $(+/+)$ at P14. (B) Histological images of back skin sagittal sections from a mouse at $10 \mathrm{~d}$ after birth with mesenchymal deletion of the $R B P-J \kappa$ gene $(-/-)$ versus an agematched control $(+/+)$; for analysis of hair follicles at earlier times, see Supplemental Figures 3 and 4. (C) Higher-magnification image of an abnormal hair follicle from a mouse with mesenchymal deletion of the $R B P-J \kappa$ gene $(-/-)$ (marked by a square in $B$ ) versus a hair follicle from an agematched control $(+/+)$. $(D, E)$ Immunofluorescence analysis of hair follicles of mice with mesenchymal deletion of the RBP-J $\kappa$ gene $(-/-)$ versus controls $(+/+)$ at $10 \mathrm{~d}$ of age with antibodies against $44-\mathrm{kDa} / 46-\mathrm{kDa}$ acidic hair keratins (AE13), trichohyalin (AE15), and cytokeratins 1 and 10. $(F)$ Real-time RT-PCR analysis of physically separated hair follicles from mice with $(-/-)$ and without $(+/)$ deletion of the RBP$J \kappa$ gene at P10, with primers specific for the indicated genes. Hair follicles from mice with deletion of the $R B P-J \kappa$ gene were analyzed separately, depending on their relatively normal (RN) and abnormal (AN) structure, and were isolated as shown in Supplemental Figure 2C. Results are expressed as relative expression levels, using $\beta$-actin for internal normalization. $(G)$ Histochemical staining of alkaline phosphatase activity in hair follicles of mice with mesenchymal deletion of the $R B P-J \kappa$ gene $(-/-)$ versus controls at $10 \mathrm{~d}$ of age. $(H)$ Immunofluorescence analysis of similar hair follicle sections (left two panels) and of cysts that develop in RBP-Jk ${ }^{-1-}$ mice by 3 wk of age (right panel) with antibodies against versican. (I) Immunofluorescence analysis of hair follicles of control and RBP-Jk mutant mice with antibodies against Sox2. Bars, $40 \mu \mathrm{m}$. 
1B,C; Supplemental Fig. 4). Immunofluorescence analysis showed substantially decreased expression of $44-\mathrm{kDa} /$ 46-kDa acidic hair keratins, a marker of cortex and cuticle layers of the hair shaft, and trichohyalin, a marker of medulla and IRS (Lynch et al. 1986), while, conversely, expression of markers normally confined to the interfollicular epidermis (cytokeratins 1 and 10) was detectable in hair follicles (Fig. 1D,E). This "switch" between hair follicle and interfollicular marker expression was further documented and quantified by real-time RT-PCR analysis of physically isolated hair follicles from the (ColI-Cre $\times$ RBP-JK ${ }^{\text {loxP/loxP }}$ ) mice and age-matched controls (Fig. 1F). Degeneration of hair follicles into cysts became widespread by $2-3$ wk, with the mature cysts exhibiting high levels of interfollicular marker expression (Supplemental Fig. 5A-C). Vibrissae hair follicles were also normal after birth, but were then lost in the mutant mice by $3-4 \mathrm{wk}$, undergoing similar cystic degeneration as pelage hair follicles (Supplemental Fig. 5D,E).

Versican and alkaline phosphatase staining showed that dermal papillae remained in contact with hair follicles as well as the cysts that formed over time (Fig. $1 \mathrm{G}, \mathrm{H})$. Expression of another dermal papilla cell marker, Sox2, was also similar in control and mutant mice (Fig. 1I). Sox2-positive dermal papilla cell populations were shown recently to be essential for production of auchene and awl hair fibers (Driskell et al. 2009). Consistent with our expression data, plucked hair analysis showed that mutant mice produced all four types of hair in an approximately normal ratio (Supplemental Fig. 6A). Reflecting the hair follicle structural defects, a large percentage of all hair types showed abnormal packing and irregular fiber profile, with aberrant restrictions and bending (Supplemental Fig. 6B).

As with many other mutations, mice with keratinocyte-specific deletion of the $R B P$ - $/ \kappa$ gene exhibit also hair follicle degeneration and cyst formation (Blanpain et al. 2006). We therefore compared in detail alterations resulting from deletion of the $R B P-J \kappa$ gene by the Cre transgene driven by a ColI versus keratin 5 (K5) promoter, using mice of a young age and at an early stage of hair follicle degeneration (Supplemental Fig. 7). In both cases, deletion of the $R B P-J \kappa$ gene resulted in markedly decreased expression of acidic hair keratins and trichohyalin, and K6 up-regulation. However, while in the /ColI-Cre $\times$ RBP$\mathrm{JK}^{\text {loxP/loxP}} /$ mice there was pronounced hair follicle expression of suprabasal interfollicular cytokeratins 1 and 10 (K1 and K10), no such expression was found in the $\left(\right.$ K5-Cre $\times$ RBP-J $\kappa^{\text {loxP/loxP }}$ ) mice (Supplemental Fig. 7B). As reported previously (Blanpain et al. 2006), K1/K10 expression was decreased even in the interfollicular epidermis of mice with keratinocyte-specific RBP-Jк deletion, while in mice with the mesenchymal deletion, expression of these genes was increased (Supplemental Fig. 7C). This was paralleled by the expected decrease of direct Notch target genes Hes1 and Hey1 in mice with the first genotype, but not in mice with the second genotype (Supplemental Fig. 7C). Besides differentiation marker expression, dermal papilla cells, as identified by versican and Sox2 staining, were normally present in the skin of mice with the ColI-Cre-driven deletion but not K5-Credriven deletion (Supplemental Fig. 7D), consistent with distinct phenotypes resulting from RBP-Jк deletion in the two skin compartments.

\section{Intrinsically defective hair-inducing capabilities of dermal papilla cells with RBP-Jк deletion}

To assess whether the phenotype of the /ColI-Cre $\times$ RBP$\mathrm{JK}^{\operatorname{lox} / / \operatorname{loxP}} \mid$ mice is skin intrinsic or secondary to systemic alterations, we resorted to full-thickness skin grafting onto nude mice. Grafts of RBP-Jк mutant skin showed aberrant hair follicle differentiation and cyst formation, as in the original mice with this mutation (Fig. 2A).

The interesting possibility exists that RBP-JK deletion in extrafollicle dermal cells contributes to the observed phenotype. To specifically establish whether the hair follicle alterations can be attributed to a defect in dermal papilla cells, we performed hair follicle reconstitution assays (Zheng et al. 2005) using freshly isolated dermal papilla cells with or without RBP-JK deletion in combination with wild-type keratinocytes. The latter were obtained from mice with a GFP transgene driven by an actin promoter (Okabe et al. 1997), which allowed unequivocal identification of hair follicles reconstituted by donor cells relative to endogenous hair follicles of the recipient mice. Efficient hair follicle formation was observed with GFPpositive keratinocytes admixed with control dermal papilla cells, while only few hair follicles $(\sim 10$-fold difference) were formed by the same keratinocytes admixed with RBP-Jк-deficient papilla cells (Fig. 2B). Instead, the latter combination of cells resulted in widespread formation of cysts, which were rarely observed in the graft controls (Fig. 2C). Immunofluorescence analysis showed that the aberrantly reconstituted hair follicles and cysts formed by GFP-positive keratinocytes in combination

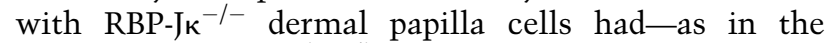
(ColI-Cre $\times$ RBP-JK ${ }^{\text {loxP/loxP}}$ ) mice-reduced acidic hair keratins and trichohyalin expression, and were positive for cytokeratins 1 and 10 (Fig. 2D).

\section{The Wnt5a gene is a direct Notch/CSL target in dermal papilla cells}

Gene expression studies were undertaken to probe into the molecular defects resulting from the RBP-Jк deletion in dermal papilla cells. As expected, real-time RT-PCR analysis showed that the "canonical" Notch-RBP-Jk target genes Hes1, Hes5, and Hey1 were down-modulated in dermal papilla cells isolated from mice with the deleted RBP-Jк gene (Fig. 3A). Expression of signaling molecules that make part of the "dermal papilla-specific signature"-Wnt5a, Fgf7, Fgf10, and Noggin-was strongly decreased in the mutant mice, while expression of other dermal papilla "signature" genes, including Sox2 (Rendl et al. 2005; Driskell et al. 2009), was maintained or even increased (Fig. 3A). Differential expression of Wnt5a, Noggin, and Fgf7/10 was confirmed at the protein level by immunoblot analysis of dermal papilla cell extracts (Fig. 3B) and immunofluorescence of corresponding skin 
A

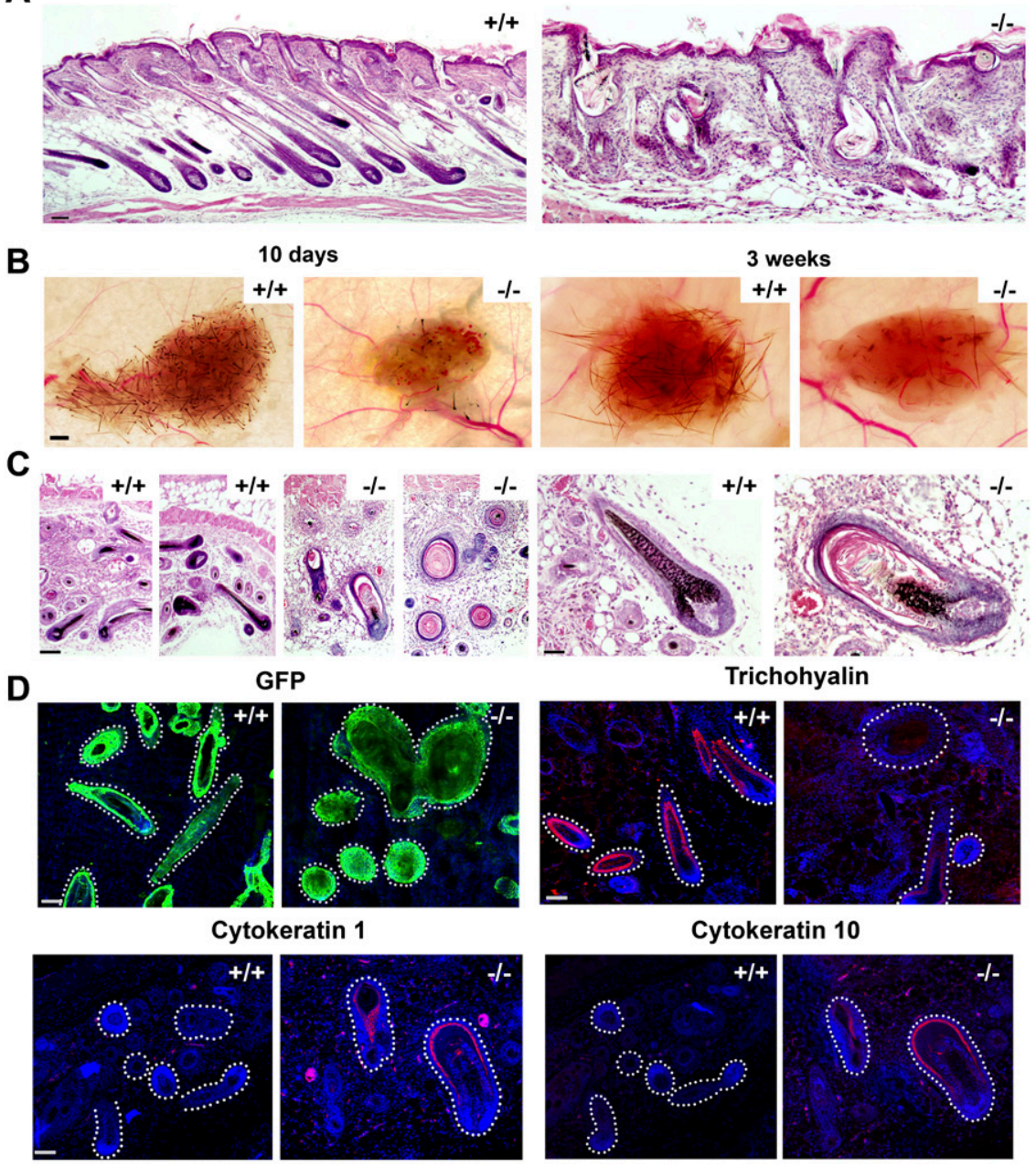

Figure 2. Intrinsically defective hairinducing capabilities of dermal papilla cells with RBP-Jк deletion. (A) Full-thickness grafting of skin from mice with and without mesenchymal RBP-Jк deletion: Back skins of (RBP-J $\kappa^{\text {loxP } / \operatorname{loxP})}(+/+)$ and RBP (Coll-Cre $\times$ RBP-JK $\left.{ }^{\text {loxP/loxP }}\right)(-/-)$ mice at $\mathrm{PO}$ were grafted in parallel onto the left and right flanks of nude mice. $\mathrm{H} \& \mathrm{E}$ staining pictures were taken 3 wk after grafting, and are representative of three independently grafted animals. Bar, 160 $\mu \mathrm{m}$. (B) Hair follicle reconstitution assays with primary keratinocytes from EGFP transgenic mice with a wild-type $R B P-J_{\kappa}$ gene, in combination with freshly isolated dermal papilla cells from (ColI-Cre $\times$ RBP$\mathrm{J}^{\left.{ }^{\text {loxP } / \text { loxP }}\right)}$ mice $(-/-)$ versus $\left(\mathrm{RBP}-\mathrm{J}^{\text {loxP } / \text { loxP }}\right.$ ) controls $(+/+)$. Results were assessed at $10 \mathrm{~d}$ and $3 \mathrm{wk}$ after grafting. Images were taken under a stereomicroscope, and are representative of four independent assays per combination of cells per time point. The average number of reconstituted hair follicles was 200-300 in the control grafts, and 20-30 in the grafts with mutant dermal papilla cells. (C) Histological H\&E analysis of hair follicle reconstitution assays with the same combination of cells as in $B$. Bars: left four panels, $40 \mu \mathrm{m}$; right two panels, $160 \mu \mathrm{m}$. (D) Immunofluorescence analysis of hair follicle reconstitution assays with the same combination of cells as in $A-C$, with antibodies against the indicated proteins. Bars, $40 \mu \mathrm{m}$. sections (Fig. 3C). Modulation of these genes, similar to that observed in vivo, was found with cultured dermal papilla cells from (ColI-Cre $\times$ RBP-JK ${ }^{\text {loxP/loxP }}$ ) mice (Fig. $3 \mathrm{D})$, as well as with dermal papilla cells with the floxed RBP-Jк gene after "acute" deletion by adenovirally mediated Cre expression (Fig. 3E).

The Wnt5a, Noggin, and Fgf7/10 genes code for diffusible factors that may be under parallel RBP-Jк control, or regulation of one of them might play a primary role on the others. To address this question, dermal papilla cells with the RBP-Jк deletion were treated with each of these factors individually, in a purified form, followed by analysis of expression of the others. As shown in Figure 4A, treatment of the RBP-JK ${ }^{-/-}$dermal papilla cells with Wnt5a rescued, to a partial extent, expression of Noggin, Fgf7, and Fgf10 expression. The converse treatment with Noggin, Fgf7, or Fgf10 had no effect on Wnt5a levels (Fig. 4B), suggesting that Wnt5a is a primary target of RBP-Jк function.

Consistent with this conclusion, activated Notch1 expression by adenoviral vector infection, or tamoxifendependent activation of a retrovirally transduced Notch1ER fusion protein (Schroeder and Just 2000), induced Wnt5a in wild-type dermal papilla cells, but not in RBP-Jкdeficient cells (Fig. 4C). Induction of Wnt5a expression was similarly observed upon endogenous Notch activation by treatment of dermal papilla cells with purified Jagged 1 ligand (Fig. 4D). Nucleotide sequence analysis of the Wnt5a gene promoter and first intronic regions showed the presence of "canonical" RBP-Jк-binding sites, to which the endogenous Notch1 protein was found to bind by chromatin immunoprecipitation (ChIP) assays with control dermal papilla cells but not cells with the RBP-Jк deletion (Fig. 4E). In parallel, luciferase reporter assays showed that activated Notch1 expression induces activity of a Wnt5a promoter construct containing RBP-Jк-binding sites, but not one with the sites deleted (Fig. 4F).

\section{Compromised hair follicle differentiation in mice with deletion of the Wnt5a gene}

Mice with homozygous deletion of the Wnt5a gene die at birth due to a number of developmental defects (Yamaguchi et al. 1999; Yang et al. 2003). So far, the consequences of Wnt5a deletion in the skin have not been analyzed. Histological analysis of E18.5 embryos showed that loss of Wnt5a, as the mesenchymal RBP-JK deletion, causes no detectable defects in hair follicle morphogenesis and differentiation at this time (data not shown). 
A

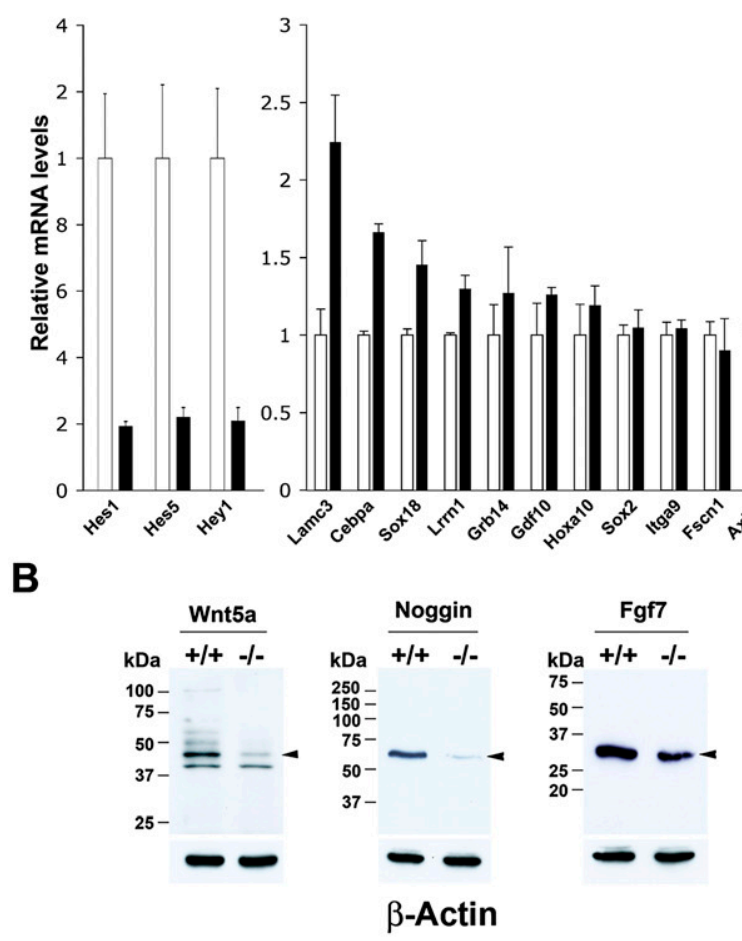

C
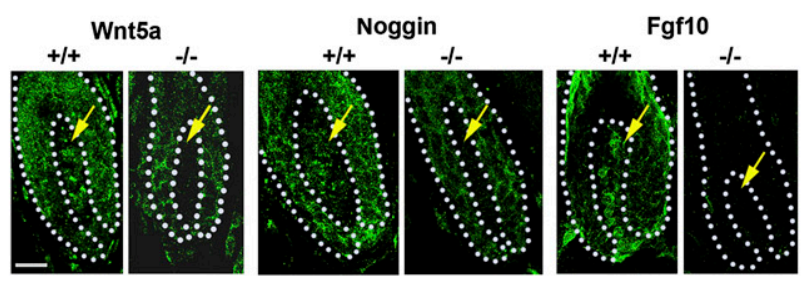

D

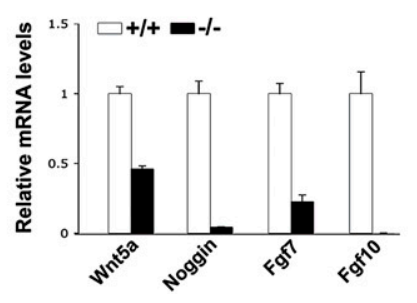

E

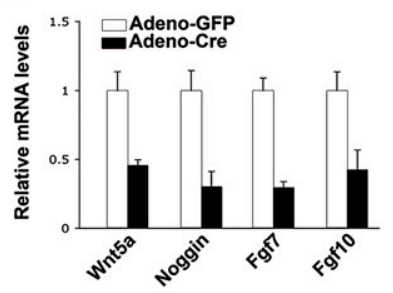

Figure 3. Changes of dermal papilla signature genes by mesenchymal deletion of the $R B P-I \kappa$ gene. $(A)$ Real-time RT-PCR analysis for expression of the indicated "canonical" Notch target genes (left panel) and dermal papilla signature genes (right panel) (Rendl et al. 2005) in freshly isolated dermal papilla cells (by the method illustrated in Supplemental Fig. 2A) from mice with mesenchymal deletion of the $R B P-J \kappa$ gene $(-/-)$ and agematched controls $(+/+)$ at day 1 after birth. Expression levels are expressed as relative values after internal normalization for $\beta$-actin. (B) Immunoblot analysis of dermal papilla cell extracts from mice with $(-/-)$ and without $(+/+)$ deletion of the $R B P-J \kappa$ gene with antibodies against the Wnt5a, Noggin, and Fgf7 proteins, using $\beta$-actin for equal loading control. The position of molecular size markers is indicated. The immunoblot for Wnt5a resulted in multiple bands, as reported in previous publications (Blumenthal et al. 2006). (C) Immunofluorescence analysis of Wnt5a, Noggin, and Fgf10 expression in anagen hair follicles of mice with and without $R B P-J \kappa$ deletion, at $10 \mathrm{~d}$ of age. Hair follicle boundaries and dermal papillae are indicated by dotted lines and arrows, respectively. (D) Real-time RT-PCR analysis of expression of the indicated genes in dermal papilla cells that were cultured from mice with $(-\mid-)$ and without $(+/+)$ deletion of the $R B P-J \kappa$ gene, at $4 \mathrm{~d}$ after plating. $(E)$ Real-time RT-PCR analysis of cultured dermal papilla cells from mice with the $R B P-J_{\kappa}$ gene flanked by loxP sites, $24 \mathrm{~h}$ after infection of these cells with a Cre-expressing adenovirus (Adeno-Cre) or AdenoGFP control. Besides the indicated genes, real-time PCR analysis with primers specific for exons 6 and 7 of the $R B P-J_{\kappa}$ gene showed $>80 \%$ deletion of this portion of the gene in the Cre-expressing cells (data not shown).
To assess the role of Wnt5a after birth, E17.5 embryo skins were grafted onto nude mice. Hair follicle abnormalities started to be seen by 1 wk after grafting of the Wnt5a mutant skin, becoming more substantial by 2 and 4 wk (Fig. 5A,B; Supplemental Fig. 8). In parallel with these alterations, immunofluorescence analysis showed consistent down-modulation of acidic hair keratins and inappropriate cytokeratin 10 expression, with dermal papilla cells (as detected by versican staining) still present (Fig. $5 \mathrm{C})$. In the latter, however, there was strong reduction of Noggin and Fgf10 expression, consistent with our other results pointing to Wnt5a as an upstream regulator of these molecules (Fig. 5D).
While Wnt5a expression is limited to dermal papilla cells during development, after birth it also extends to the keratinocyte compartment (Reddy et al. 2001; Rendl et al. 2005). To determine to what extent the hair follicle alterations of the Wnt $5 \mathrm{a}^{-/-}$grafted skin can be attributed to defective dermal papilla cell function, hair follicle reconstitution assays were undertaken with dermal papilla cells isolated from $\mathrm{Wnt} 5 \mathrm{a}^{-/-}$versus control littermates in combination with keratinocytes harboring an intact Wnt5a gene and expressing GFP. Wnt5a-deficient dermal papilla cells, like those with the RBP-Jк deletion, were similarly impaired in their hair follicle-inductive properties, inducing instead extensive cyst formation 
Hu et al.

A

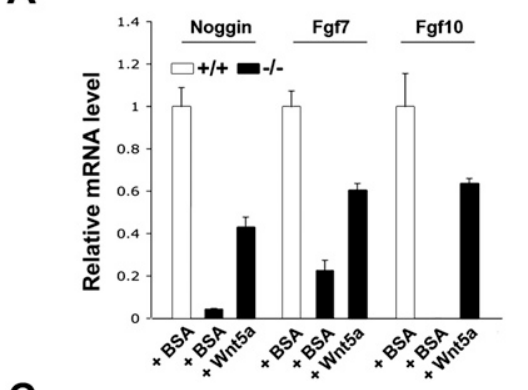

C

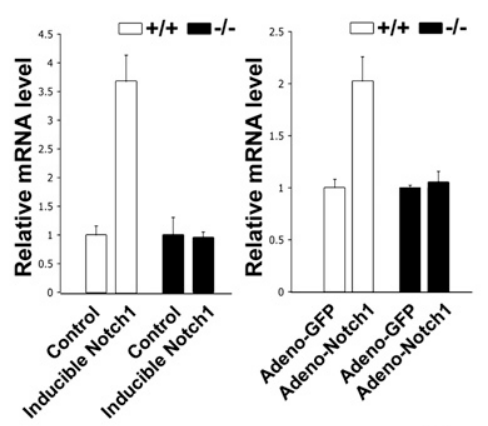

E
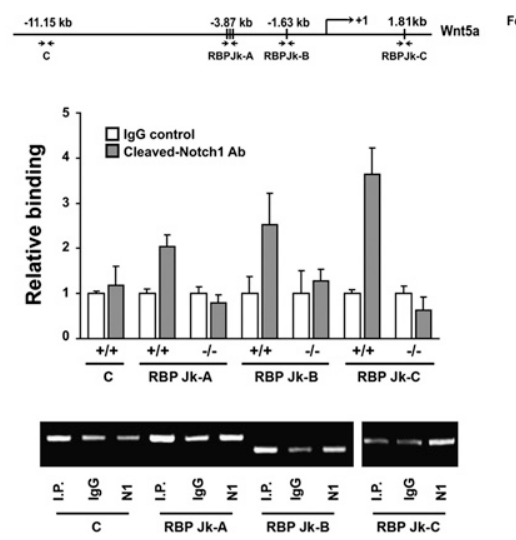

D

B

$\mathbf{F}$
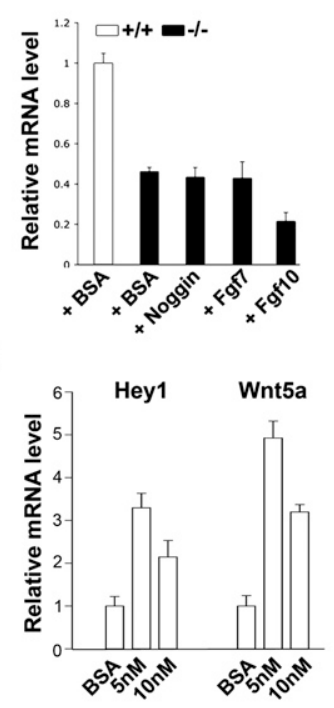

B
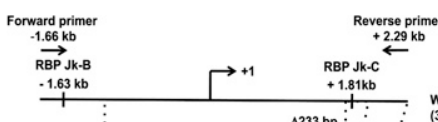
$\stackrel{R B P J k-C}{+1.81 k b}$ $W_{(3.95 \mathrm{~kb})}^{\text {Wnt-Wuc }}$
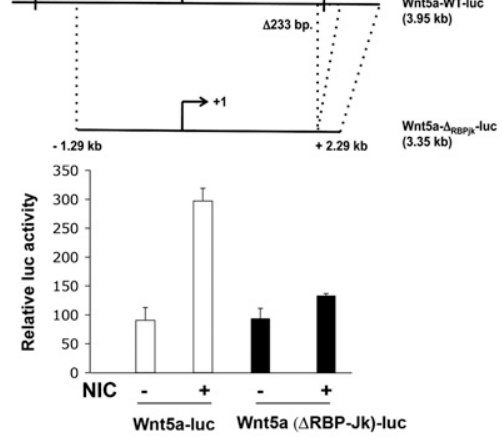

Figure 4. The Wnt5a gene as a primary target of Notch/RBP-Jк-dependent transcription in dermal papilla cells. (A) Cultured dermal papilla cells from (ColI-Cre $\times$ RBP-J $\kappa^{\text {loxP/loxP }}$ ) mice $(-/-)$ were treated with purified recombinant Wnt5a (200 ng/ $\mathrm{mL}$ ) or BSA control for $24 \mathrm{~h}$. Cells were analyzed in parallel with control cells from (RBP-Jא ${ }^{\circ}$ oxP/loxP) mice $(+/+)$ for levels of Noggin, Fgf7, and Fgf10 expression by real-time RT-PCR. $\beta$-Actin mRNA levels were used for internal normalization. $(B)$ Parallel cultures as in $A$ were treated with purified Noggin (200 ng/mL), Fgf7 (200 ng/mL), and Fgf10 $(200 \mathrm{ng} / \mathrm{mL})$, followed by real-time RT-PCR analysis of Wnt5a expression. (C) Real-time RT-PCR analysis of Wnt5a expression levels in cultured

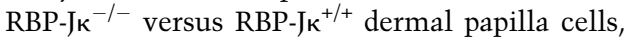
infected with a retrovirus expressing an activated Notch1-ER fusion protein, after a 24-h 4-OHT treatment (left panel) (Schroeder and Just 2000), or with an activated Notch 1-expressing adenovirus (right panel), along with corresponding controls. (D) Primary passage wild-type dermal papilla cells were plated on dishes coated with BSA or purified Jagged 1 protein, in the indicated concentrations of coating solution, for $24 \mathrm{~h}$, followed by real-time RT-PCR analysis of the "canonical" Notch target gene Hey1 and Wnt5a. (E) Cultured dermal papilla cells from mice with $(-/-)$ and without $(+/+)$ deletion of the RBP-Jк gene were processed for ChIP assays with an antibody against the proteolytically cleaved active form of Notch1 and purified rabbit IgG as nonimmune control. Realtime PCR of three distinct regions of the Wnt5a gene containing conserved RBP-Jк-binding sites at positions $-3.87 \mathrm{~kb}$ (RBP-Jк-A), $-1.63 \mathrm{~kb}$ (RBP$\mathrm{J \kappa}-\mathrm{B})$, and $+1.81 \mathrm{~kb}$ (RBP-Јк-C) from the transcription start site (see map above) were performed along with PCR of an upstream region (C) devoid of such sites. Unprecipitated chromatin preparations were similarly analyzed and used as "input DNA" control. The amount of precipitated DNA was calculated relative to the total input chromatin, and was expressed as percentage of the total

according to the following formula: percentage total $=2^{\Delta \mathrm{Ct}} \times 5$, where $\Delta \mathrm{Ct}=\mathrm{Ct}$ (input) $-\mathrm{Ct}$ (immunoprecipitation). (Ct) Cycle threshold of the real-time RT-PCR. (Bottom panel) Gel electrophoresis of the PCR products at the end of the real-time RT-PCR, showing, in each case, single-amplified DNA bands of the expected size. (I.P.) input DNA; (N1) Notch1 immunoprecipitate; (IgG) nonimmune control. The primers used to amplify these Wnt5a promoter regions are listed in Supplemental Table S1. (F) Saos2 cells were transfected with a luciferase reporter plasmid harboring a fragment of the mouse Wnt5a promoter and first intronic region containing the RBP-Jк-B- and RBP-JкC-binding sites (Wnt5a-luc; white bars), and a derivative plasmid with these sites deleted as in the map above (Wnt5a[DRBP-Jk]-luc; black bars), with (+) and without (-) an expression vector for activated Notch1 or empty vector control. Promoter activity assays were performed $48 \mathrm{~h}$ later. Values are expressed in arbitrary units after assessment of renilla reporter activity used for internal normalization (for details, see the Materials and Methods).

(Fig. 5E,F). Even in this case, immunofluorescence analysis showed down-modulation of hair follicle differentiation markers and inappropriate cytokeratin 1 expression (Fig. 5G).

\section{Functional rescue of defective $R B P-\mathrm{J}^{-/-}$hair follicles by Wnt $5 a$}

To assess whether the defects caused by deletion of RBP-Jк can be attributed to decreased Wnt5a expression, intact skin of postnatal day $4(\mathrm{P} 4)$ mice was placed in culture and incubated for $4 \mathrm{~d}$ in either the presence or absence of exogenous Wnt5a. The fraction of hair follicles undergoing cystic degeneration over a 4-d incubation period was significantly decreased as a consequence of Wnt5a treatment (Fig. 6A,B). In parallel, hair follicle differentiation-related genes were up-regulated and interfollicular markers were down-modulated in hair follicles isolated from the Wnt5atreated skins (Fig. 6C). Similar rescue of gene expression defects was observed when purified follicles from the mutant mice, instead of skin explants, were placed in culture and directly treated with Wnt5a (Fig. 6D). 
A

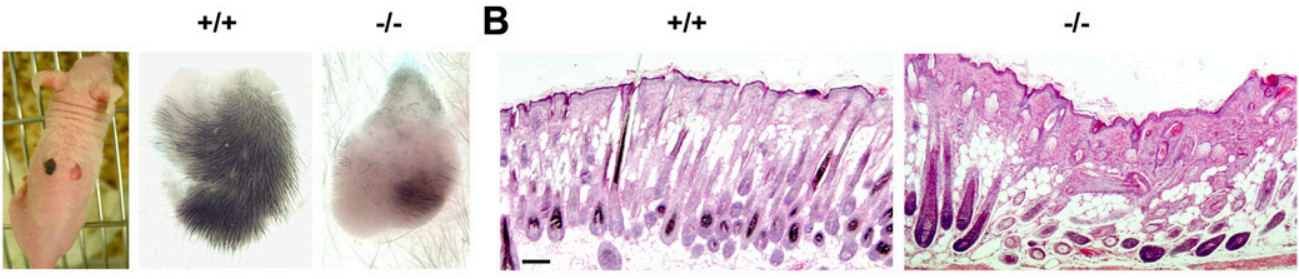

C
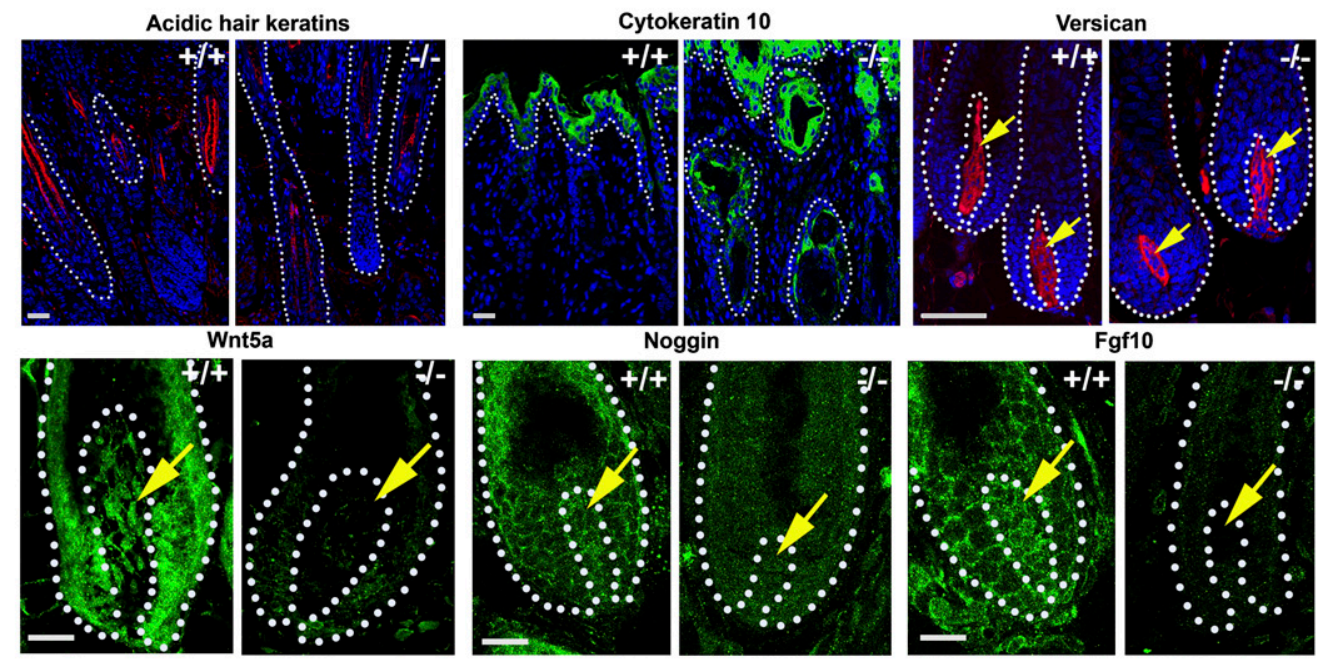

E
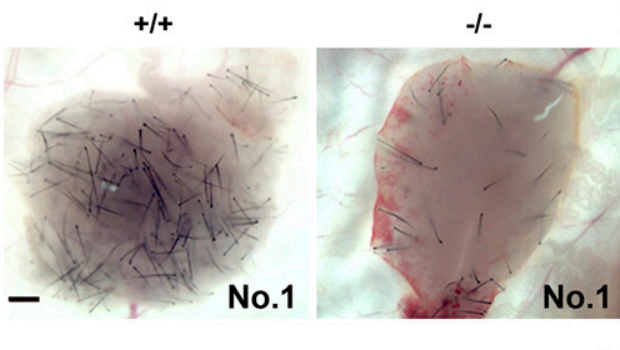

F $\quad+/+$
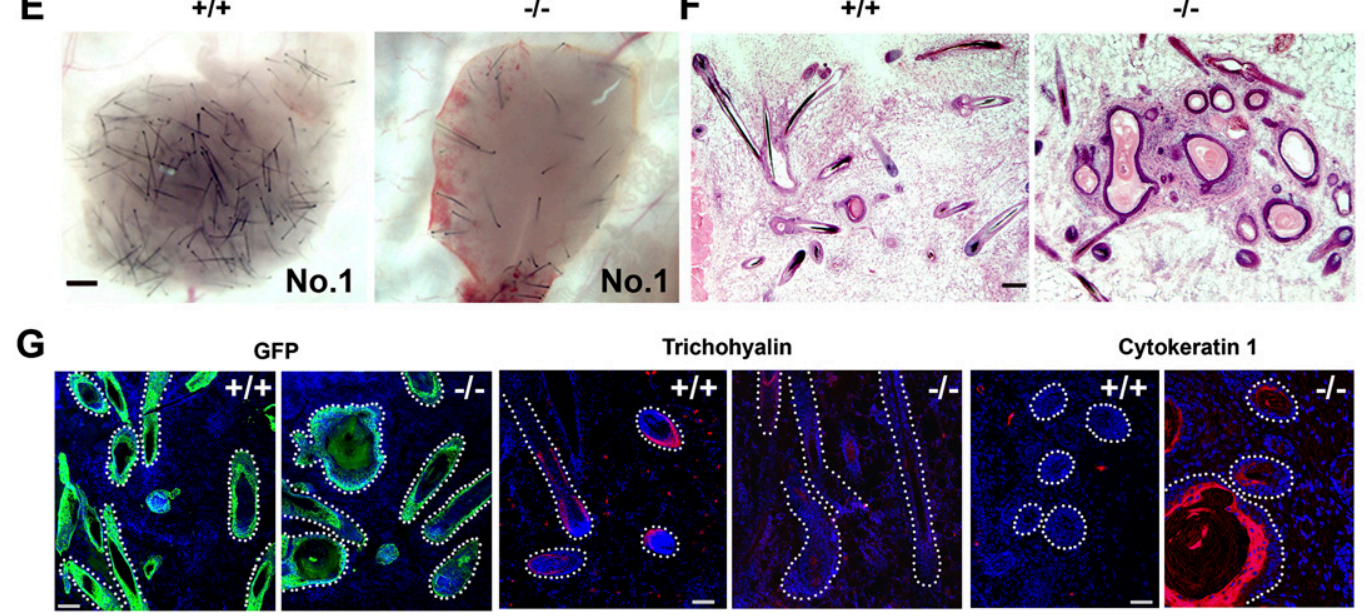

Cytokeratin 1

Figure 5. Defective hair follicle differentiation as a consequence of Wnt5a deletion in grafted skin and hair follicle reconstitution assays. (A) Full-thickness skin of E17.5 mouse embryos with homozygous deletion of the Wnt5a gene was grafted in parallel with skin of wild-type littermates onto the backs of nude mice. Photographs are representative of three grafted animals at 1 wk after grafting. Results of grafts at 2 and 4 wk are shown in Supplemental Figure 8. (B) Histological analysis of the corresponding skin samples illustrated in $A$. Hair follicle density, assessed by counting two grafts per group, was $16 \pm 4$ and $13 \pm 2$ follicles per millimeter for wildtype and mutant grafts, respectively $(P<0.01$ by Students $t$-test). Bar, $160 \mu \mathrm{m} .(C)$ Immunofluorescence analysis of mutant versus control skin at $7 \mathrm{~d}$ after grafting with antibodies against the indicated proteins. Bar, $40 \mu \mathrm{m}$. $(D)$ Immunofluorescence analysis of Wnt5a, Noggin, and Fgf10 expression in hair follicle and dermal papillae of mutant versus control skin at $7 \mathrm{~d}$ after grafting. Hair follicle boundaries and dermal papillae are indicated by dotted lines and arrows, respectively. Images were taken under the same exposure and capture conditions, and are representative of multiple hair follicles of similar developmental stages in two grafts per condition. Bar, 30 $\mu \mathrm{m}$. (E) Hair follicle reconstitution assays with primary keratinocytes from EGFP transgenic mice in combination with freshly isolated dermal papilla cells from E18.5 Wnt5a mutant embryos (-) - ) versus wild-type littermates $(+/+)$. Stereomicrographs are representative of four independent assays per combination of cells, at 2 wk after grafting. Average number of reconstituted hair follicles was 150-200 in the control grafts, and 20-40 in the grafts with mutant dermal papilla cells. Bars, $400 \mu \mathrm{m}$. $(F)$ Histological analysis of hair follicle reconstitution assays described in $E$. Bar, $100 \mu \mathrm{m}$. (G) Immunofluorescence analysis of hair follicle reconstitution assays with antibody against the indicated proteins. Epithelial-mesenchymal borders are indicated by dotted lines. Bar, $40 \mu \mathrm{m}$. 
Hu et al.
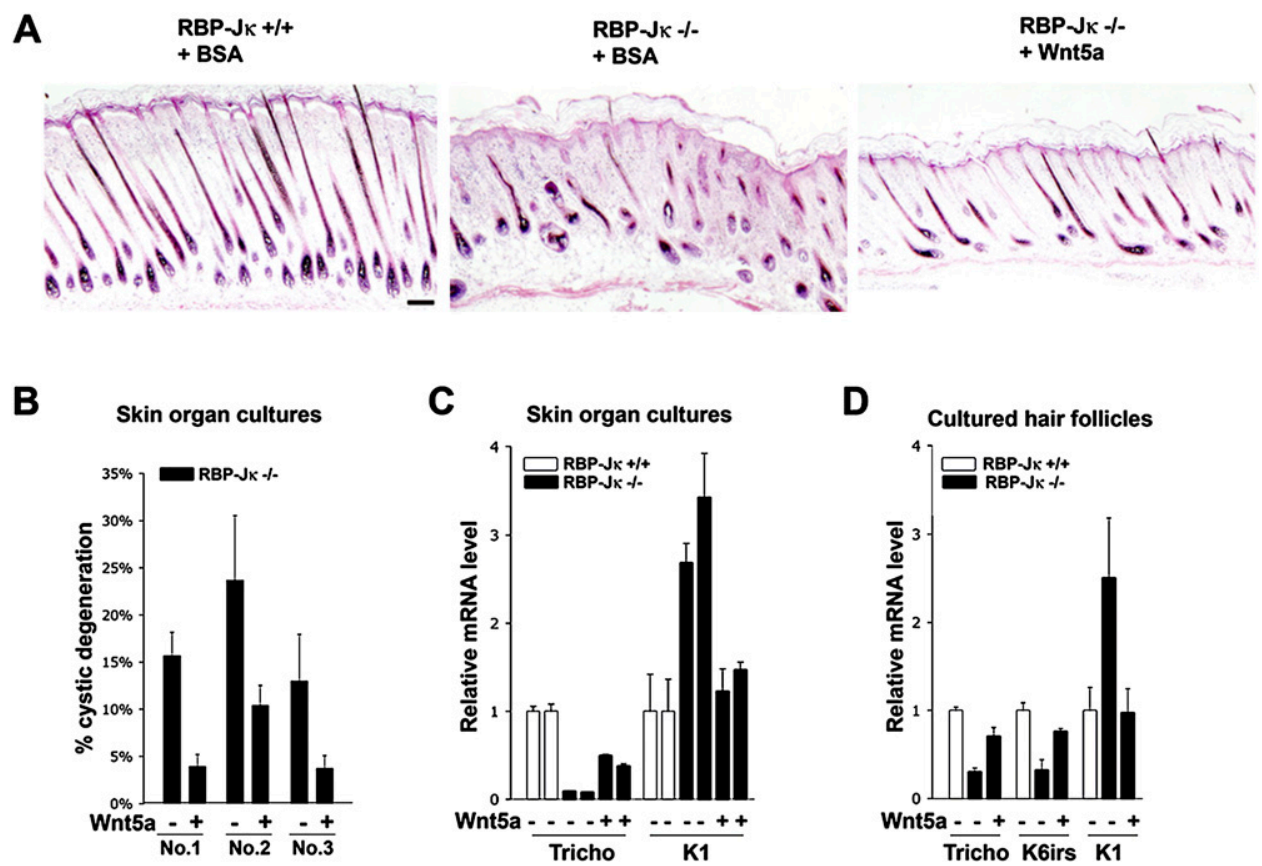

Figure 6. Functional rescue of skin organ cultures by Wnt5a treatment. $(A)$ Triplicate back skin samples from P4 (ColI-Cre $\times$ RBP$\left.\mathrm{J}{ }^{\operatorname{loxP} / \operatorname{loxP}}\right)$ mice $(-/-)$ were cultured for $4 \mathrm{~d}$ in the presence of Wnt5a $(200 \mathrm{ng} / \mathrm{mL})$ or BSA, in parallel with skin of wild-type littermates $(+/+)$, followed by histological analysis. Bar, $100 \mu \mathrm{m} .(B)$ Quantification of cystic degeneration in the skin of mice (three mice per condition) with the RBP-Jк deletion $(-/-)$, cultured in the presence or absence of Wnt5a, as indicated in $A$. Two-hundred hair follicles were counted in each skin, and the percentage of hair follicles showing signs of cystic degeneration (with alterations similar to those shown in Fig. 2C) was determined. $(C)$ Hair follicles from organ skin cultures with $(+)$ and without $(-)$ Wnt5a treatment as in $A$ were enzymatically isolated, followed by total RNA preparation and real-time RT-PCR analysis of trichohyalin and cytokeratin 1 expression. Hair follicles from cultured skins of two independent mice per condition were analyzed. $(D)$ Hair follicles isolated from the skins of P0 mice with $(-/-)$ and without $(+/+)$ deletion of the RBP-Jк gene were cultured in the presence or absence of exogenous Wnt5a $(200 \mathrm{ng} / \mathrm{mL}$ ) for $48 \mathrm{~h}$, followed by total RNA preparation and real-time RT-PCR analysis of the indicated genes.

FoxN1 as a target and mediator of RBP-JK/Wnt5a signaling in hair follicles

Wnt5a has been implicated as an activator of noncanonical Wnt signaling, although, in some contexts, it can also induce the canonical pathway (Mikels and Nusse 2006). In the functional rescue experiments above, real-time RT-PCR analysis of isolated hair follicles from cultured skin showed that Wnt5a treatment caused no modulation of canonical Wnt target genes like Lef1, Axin2, or DKK1. In contrast, expression of FoxN1, a keratinocyte-specific transcription factor reported previously to be under Wnt control (Balciunaite et al. 2002), was substantially induced (Fig. 7A). Immunofluorescence analysis confirmed that Wnt5a treatment caused a significant increase of FoxN1 expression in hair follicles of cultured (ColI-Cre $\times$ RBP-Jא ${ }^{\text {loxP/loxP }}$ ) skin (Fig. 7B). Levels of FoxN1 expression were similarly analyzed in hair follicle reconstitution assays with dermal papilla cells with or without deletion of the $R B P-J_{\kappa}$ and $W n t 5 a$ genes. The results indicated that sustained FoxN1 expression is under dermal papilla cell control through a RBP-Jк- and Wnt5a-dependent mechanism (Fig. 7C,D).

A number of transcriptional targets of FoxN1 have been reported previously, including Phospholipase C- $\delta 1$ (Plcd1) (Janes et al. 2004; Nakamura et al. 2008) and desmocollin 2 (DSC2) (Johns et al. 2005). Similar downmodulation of these genes, as well as trichohyalin, was found in cultured hair follicles with siRNA-mediated knockdown of FoxN1 expression as in hair follicles derived from mice with the RBP-Jк deletion (Fig. 7E,F). Conversely, Wnt5a treatment led to induction of these genes in wild-type hair follicles, with no such induction occurring in similarly treated hair follicles derived from FoxN1 mutant mice (Fig. 7G).

\section{Involvement of the Wnt5a receptors ROR2 and Fzd6 in control of FoxN1 expression}

Wnt5a can function through multiple receptors, like the Frizzled family member Fzd6 and ROR2, a transmembrane tyrosine kinase with an extracellular Fzd-like cystein-rich domain (van Amerongen et al. 2008). Real-time RT-PCR analysis showed that expression of both receptors is reduced in hair follicles as a consequence of RBP-Jк or Wnt5a deletion (Supplemental Fig. 9A), and is induced by Wnt5a treatment (Supplemental Fig. 9B), consistent with a positive feedback regulatory mechanism reported in other systems (O'Connell et al. 2010). Functionally, knockdown of ROR2 in hair follicles led to down-modulation of FoxN1 (Supplemental Fig. 9C) and suppressed induction of this gene, as well as its downstream targets, by Wnt5a treatment 
A

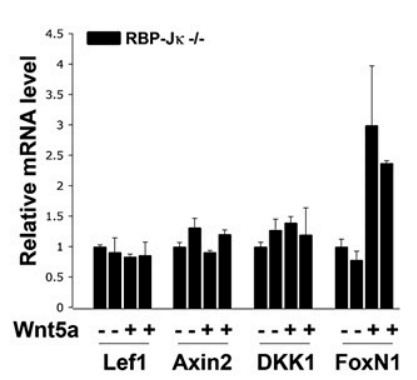

B

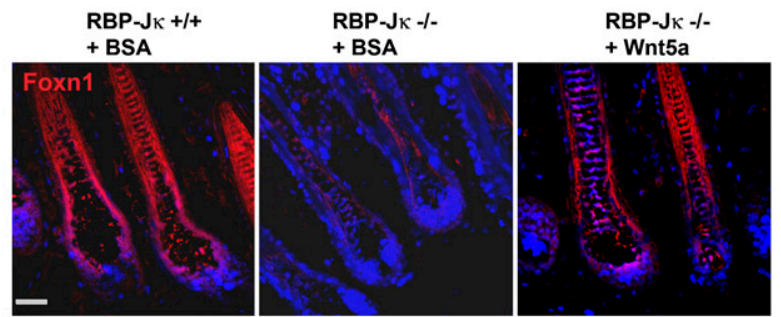

C
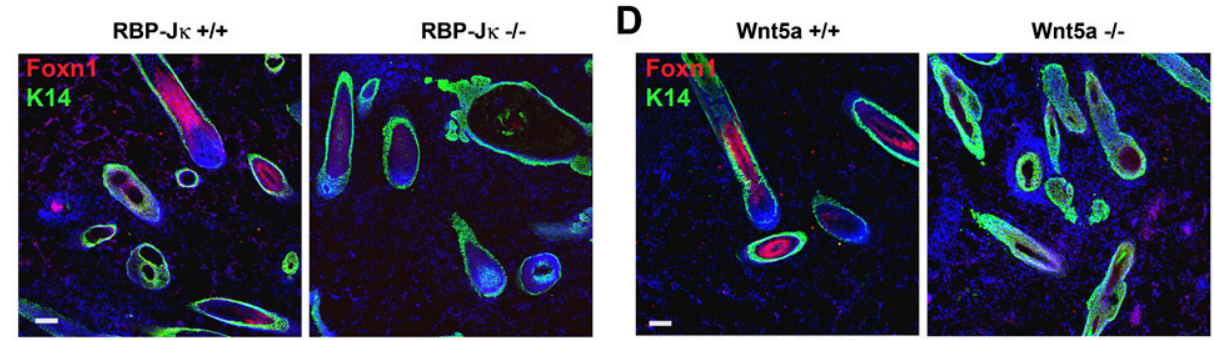

$\mathbf{E}$

$\mathbf{F}$
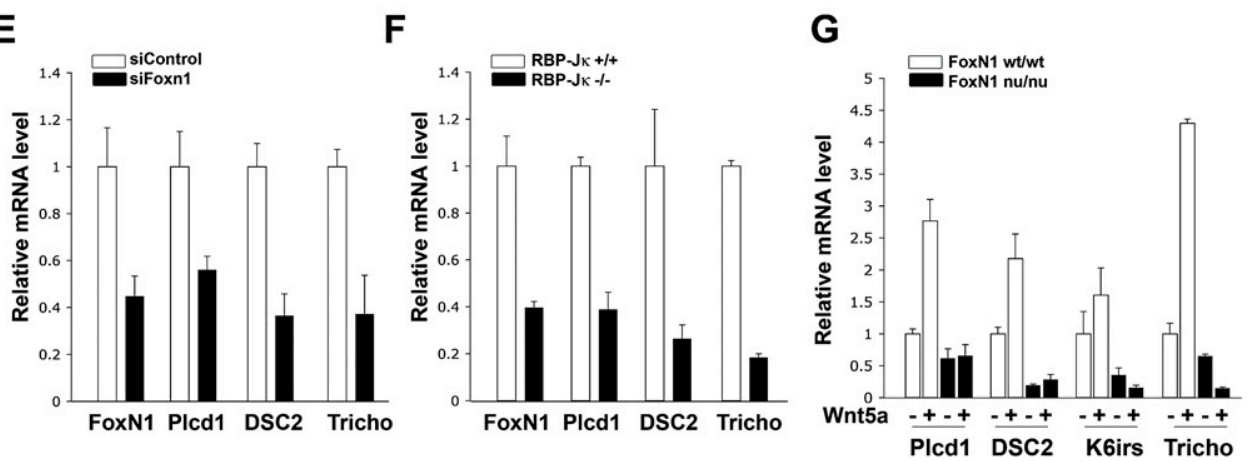

Figure 7. Effects of FoxN1 as a mediator of Wnt5a on hair follicle gene expression. $(A)$ Hair follicles from organ skin cultures with $(+)$ and without (-) Wnt5a treatment (as in Fig. 6) were analyzed by real-time RT-PCR for expression of the indicated genes. Hair follicles from the cultured skins of two independent mice per condition were analyzed. (B) Immunofluorescence analysis of FoxN1 expression in the skin of mice with RBP-Jк deletion $(-/-)$ and littermate controls $(+/+)$, cultured in the presence or absence of recombinant Wnt5a for $4 \mathrm{~d}$. DAPI staining was used for nuclear visualization. Bar, $40 \mu \mathrm{m} .(C, D)$ Double-immunofluorescence analysis with antibodies against FoxN1 (red) and K14 (green) expression in hair follicle reconstitution assays with dermal papilla cells with deletion of the RBP-Jк (C) or Wnt5a $(D)$ genes in parallel with wild-type controls. Experiments were as described for Figures 2, B-D, and 5, E-G. DAPI staining was used for nuclear visualization. Bar, $40 \mu \mathrm{m}$. (E) Real-time RT-PCR analysis of physically separated hair follicles from newborn mice (P0) with $(-/-)$ and without $(+/+)$ deletion of the $R B P-J_{\kappa}$ gene, with primers specific for the indicated genes. $(F)$ Hair follicles from wild-type newborn mice (P0) (purified and cultured as described in the Materials and Methods) were transfected with anti-FoxN1 siRNAs in parallel with scrambled controls, followed $96 \mathrm{~h}$ later by real-time RT-PCR analysis of expression of the indicated genes. (G) Hair follicles isolated from the skins of mice with $(-/-)$ and without $(+/+)$ mutation of the FoxN1 gene and cultured in the presence or absence of exogenous Wnt5a for $48 \mathrm{~h}$ were analyzed for expression of the indicated genes by real-time RT-PCR.

(Supplemental Fig. 9D). Similar results were observed after Fzd6 knockdown (Supplemental Fig. 9E,F).

We complemented the above findings by assessing the consequences of loss of ROR2 function in vivo. Mice with homozygous disruption of the ROR2 gene die at birth due to breathing defects (Takeuchi et al. 2000). Immunofluoresence analysis of the skin of these mice after fullthickness grafting onto nude mice revealed that expression of FoxN1 as well as trichohyalin was reduced consistently in the hair follicles of these mice (Supplemental Fig. 10A,B). However, this was associated with only slight alterations in hair follicle structures (in IRS and/or hair shaft organization) that did not proceed to overt cyst formation, consistent with ROR2 functioning in concert with Fzd6 and possibly other Wnt5a receptors.

\section{Discussion}

Epithelial-mesenchymal interactions play a key role in organ morphogenesis and homeostasis. Hair follicle development and cycling provide a model paradigm for these interactions (Botchkarev and Paus 2003). In this system, the function of Notch signaling in the epithelial compartment has been studied extensively, while its role in the neighboring inductive mesenchyme has not been investigated. We unveiled an as yet unsuspected mechanism for 
maintenance of the hair follicle keratinocyte cell fate by underlying dermal papilla cells through the CSL/RBP-Jא gene, the mediator of "canonical" Notch signaling. Wnt5a functions as a primary CSL effector in these cells, with FoxN1 as one of its targets in keratinocytes.

Significant attention has been given to the role of Notch signaling in control of keratinocyte stem cell potential and differentiation. Deletions of the RBP-JK (Yamamoto et al. 2003; Blanpain et al. 2006; Demehri and Kopan 2009), Notch1 and Notch2 (Pan et al. 2004), and Jagged 1 (Estrach et al. 2006) genes in keratinocytes cause loss of hair follicles, with replacement of these structures with cysts. We found similar alterations in mice with mesenchymal deletion of the $R B P-J \kappa$ gene. However, comparative analysis of these mice with those with keratinocyte-specific deletion of the same gene pointed to distinct molecular defects, with likely different underlying mechanisms. In mice with the ColI-Cre deletion of RBP-Jк, there was inappropriate hair follicle expression of suprabasal interfollicular keratins (K1 and K10), which were not found in hair follicles of mice with the K5-Cre deletion. While dermal papilla cells (identified by versican, alkaline phosphatase, and Sox 2 staining) were normally present in mice with the first genotype, they were hard to find in the others. The impact that loss of RBP-Jк function in keratinocytes has on underlying dermal papilla cells will have to be assessed in future studies. Here, by hair follicle reconstitution assays, we showed that the $R B P-J_{\kappa}$ gene plays an intrinsic essential role in dermal papilla cells. Deletion of this gene did not compromise cell fate identity, as assessed by a panel of dermal papilla signature genes. Rather, it resulted in decreased expression of diffusible molecules that act as cues to overlying keratinocytes. Analysis of late gestation embryos and mice of early age indicates that dermal papilla cells lacking the RBP-Jk gene are not impaired in their overall ability to contribute to hair follicle morphogenesis, but in subsequent steps required for hair follicle maturation and/or differentiation.

Wnt5a is a specific Wnt family member whose expression during early skin development is limited to dermal papillae (Rendl et al. 2005), with only later expression in the hair follicle compartment (Reddy et al. 2001). Wnt5a expression in the developing skin is dependent on Shh function, and Wnt5a has been proposed as a mediator of the "second dermal signal" required for hair follicle proliferation downstream from Shh expression in the overlying epithelium (Reddy et al. 2001). Wnt5a expression has also been connected with the site-specific function of dermal fibroblasts in the body, under transcription control of the distal site-specific homeobox gene HOXA13 (Rinn et al. 2008). Our present findings point to Wnt5a as a likely direct target of Notch/RBP-JK function in dermal papilla cells, as the promoter and first intronic region of the Wnt5a gene contain RBP-Jк-binding sites to which endogenous Notch1 binds, and which are required for Notch1-dependent promoter activation.

Hair follicle reconstitution assays with dermal papilla cells from mice with mesenchymal RBP-Jк deletion or deletion of the Wnt5a gene point to a common function of the two genes in these cells. In fact, functional rescue experiments indicate that Wnt5a is a primary mediator of RBP-Jא function in this context, with other diffusible molecules involved in dermal papilla signaling, like Noggin and Fgf7/10, being under more indirect RBP-JK/Wnt5a control. Interestingly, the demonstrated ability of Wnt5a to induce JNK/c-Jun activity (Pukrop et al. 2006; Nomachi et al. 2008) could underlie its regulation of Fgf7 expression, which was found to be under c-Jun control in the skin (Szabowski et al. 2000). Future studies will have to assess to what extent this and other factors synergize or antagonize with Wnt5a function in this context.

Downstream from RBP-Jk/Wnt5a, we found that expression of the FoxN1 transcription factor is compromised in the keratinocyte compartment. FoxN1 plays an important role in control of hair follicle keratinocyte differentiation (Mecklenburg et al. 2001). Genes under FoxN1 control are down-modulated as a consequence of the RBP-JK/Wnt5a deletions, and are up-regulated in hair follicles by Wnt5a treatment in a FoxN1-dependent manner, implicating this transcription factor as a mediator of RBP-JK/Wnt5a activity in hair follicles. FoxN1 has also been implicated in providing the necessary cues for specific transfer of pigment from melanocytes to keratinocytes of the hair shaft cortex (Weiner et al. 2007). Reduced pigment deposition in the hair cortex was found in hair follicles of RBP-Jк or Wnt5a mutant mice or grafts, as well as in hair follicle reconstitution assays with corresponding dermal papilla cells (Supplemental Fig. 11), consistent with our other findings of decreased FoxN1 expression and activity.

Little is known about control of this gene. In thymic epithelia, FoxN1 expression is positively modulated by Wnt4 and/or Wnt5b (Balciunaite et al. 2002), whereas it is negatively regulated by ERK $1 / 2$ activity in keratinocytes (Baxter and Brissette 2002; Mandinova et al. 2009). The data we presented indicate that FoxN1 expression in hair follicles is under positive Wnt5a control, as it is downregulated in the skin of mice with deletion of the Wnt5a gene and in reconstituted hair follicles with Wnt5a-null dermal papilla cells, while it is induced in wild-type hair follicles by Wnt5a treatment. Wnt5a has been most frequently linked to "noncanonical" Wnt signaling, through multiple receptors leading to activation of calcium- and Rho/JNK-dependent pathways (van Amerongen et al. 2008). Knockdown experiments indicate that two of these receptors, Fzd6 (Wang and Nathans 2007) and ROR2 (Oishi et al. 1999|, participate in control of FoxN1 expression by Wnt5a. Studies from other systems indicate that these proteins have the potential to functionally and physically interact (Yamamoto et al. 2008). Little or nothing is known about the signaling function of these receptors in keratinocytes, and an exciting line of future work will involve the elucidation of their role in the regulatory axis that we uncovered.

\section{Materials and methods}

Mice

RBP-JK ${ }^{\text {loxp/loxp }}$ mice (Han et al. 2002) were crossed with transgenic mice expressing a Cre recombinase under control of the 
promoter/enhancer unit of the $\alpha 2$ chain of the collagen type $I$ gene (Florin et al. 2004) or the keratin 5 promoter (Berton et al. $2000)$ to generate $\left(\right.$ ColI-Cre $\times$ RBP-Jא $\left.{ }^{\text {loxP/loxP }}\right)$ and $($ K5 - Cre $\times$ RBP$\mathrm{J \kappa}^{\text {loxP/loxP }}$ ) mice, respectively. (Coll-Cre $\times$ RBP-J ${ }^{\text {loxP } / \text { wt }}$ ) mice were also crossed into the ROSA 26R reporter strain, an in vivo reporter of Cre activity (Soriano 1999). Transgenic mice with EGFP expression driven by a ubiquitous $\beta$-actin promoter (C57BL/6-Tg [Act-EGFP]) were described (Okabe et al. 1997). B6;129S7-Wnt5a ${ }^{\text {tmlAmc }} / \mathrm{J}$ mice (Yamaguchi et al. 1999) were purchased from The Jackson Laboratory, and NMRI wild-type and Nude mutant (heterozygotes and homozygotes) were from Center d'Elevage R. Janvier. ROR2 knockout mice were described previously (Oishi et al. 1999). All mouse work except for ROR2 mice was performed according to the Swiss guidelines and regulations for the care and use of laboratory animals. For ROR2 mice, work was performed according to International Animal Care and Use Committee guidelines and regulations of Tulane University.

\section{Skin cell preparation and purification}

The whole procedure is illustrated in Supplemental Figure 2A, along with expression analysis of various markers to assess the effectiveness of the separation procedure. For separation of interfollicular epidermis from the dermis, back skin from P1 mice was treated with $1 \%$ Dispase II (Roche) overnight at $4^{\circ} \mathrm{C}$. For hair follicle separation, the dermis was further digested by $0.3 \%$ type I collagenase (Sigma) in HBSS (Gibco) for $1 \mathrm{~h}$ at $37^{\circ} \mathrm{C}$. After centrifugation in a tabletop centrifuge (1000 rpm for $5 \mathrm{~min}$, followed by $400 \mathrm{rpm}$ for $5 \mathrm{~min}$ twice), the sedimented material was subjected to two rounds of density gradient centrifugation-the first in $10 \%$ Percoll $(d=1.01)$, and the second in $33 \%$ Percoll $(d=$ 1.05 - collecting the bottom fraction each time. Microscopic examination showed $>90 \%$ hair follicle purification by this approach. The recovered hair follicles were further dissociated into cell suspension by mechanical disruption (20 strokes through a 23-gauge and then a 26-gauge needle). Cells were then centrifuged and resuspended into $500 \mu \mathrm{L}$ of culture medium and incubated with rat anti-mouse c-Kit (eBioscience) and rat antimouse CD133 (eBioscience) antibodies (at a 1:100 dilution) for 1 $\mathrm{h}$ at room temperature. Cells were then washed twice in culture medium, followed by incubation with goat anti-rat microbeads (Miltenyi Biotech) for $30 \mathrm{~min}$ at $4^{\circ} \mathrm{C}$. Magnetic cell sorting, using a MACS midi separator and LS columns (Miltenyi Biotech), was then used to deplete cells positive for c-Kit (melanocytes) and CD133 (dermal papilla cells), and the remaining cells (hair follicle keratinocytes) were used for further analysis.

For separation of dermal papilla cells and dermal fibroblasts, cells from $1 \%$ collagenase-treated dermis were collected by centrifugation, followed by resuspension in $500 \mu \mathrm{L}$ of culture medium and incubation with rat anti-mouse c-Kit and rat antimouse CD34 (Abcam) antibodies (1:100). Magnetic cell sorting was used to remove the c-Kit-positive (melanocytes) and CD34positive (endothelial) cells. Cells recovered after this depletion procedure were further incubated with rat anti-mouse CD133 antibodies, and magnetic cell sorting was used to separate them in into a CD133-positive fraction (dermal papilla cells) and CD133-negative fraction (dermal fibroblasts). For hair follicle reconstitution and dermal papilla cell culture assays, dermal papilla cells were directly isolated from dermal cell preparations by magnetic cell sorting with anti-CD133 antibodies.

For the isolation of mature hair follicles (from P10 mice) and cysts (from 3-wk-old mice), the total skin was at first digested in $1 \%$ type I collagenase for $2 \mathrm{~h}$ at $37^{\circ} \mathrm{C}$. Hair follicles and cysts were then purified by the two-step density gradient centrifugation described above. Hair follicles with relatively normal versus abnormal structures from the (ColI-Cre $\times$ RBP-J $\left.\kappa^{\operatorname{loxP} / \operatorname{lox} P}\right)$ mice, as well as the cysts, were further manually isolated under a dissecting stereomicroscope (Leica MZ 16F).

\section{Cell culture, viral infection, and plasmids}

For culturing, the sorted dermal papilla cells from newborn mice were plated at an initial density of $2 \times 10^{5}$ per $10-\mathrm{cm}$ dish and cultured in DMEM (Gibco) and 10\% fetal bovine serum (FBS) (Sigma) for $3 \mathrm{~d}$ (to $60 \%-70 \%$ confluence) prior to further analysis. For in vitro deletion of the $R B P-J \kappa$ gene, cultured dermal papilla cells from $\left(\mathrm{RBP}-\mathrm{J}_{\mathrm{K}}{ }^{\text {loxP/loxP }}\right)$ mice were infected with an adenovirus expressing activated Notch1 or the Cre recombinase together with GFP, in parallel with a control virus expressing GFP alone, at a multiplicity of infection of 100 , which resulted in $>99 \%$ of GFP-positive infected cells. Adenoviruses and our conditions for adenovirus production and infection were as reported previously (Rangarajan et al. 2001). As an alternative approach, dermal papilla cells were infected with a retrovirus expressing constitutively active Notch 1 fused to an estrogen receptor domain (rNERT-neo) (Schroeder and Just 2000) and empty vector control (rneo), followed $4 \mathrm{~d}$ later by treatment with $1 \mu \mathrm{M}$ 4-hydroxytamoxifen (OHT) for $48 \mathrm{~h}$ to induce nuclear translocation and activation of Notch-dependent transcription.

For treatment of dermal papilla cells with Jagged 1 ligand, 2 $\mathrm{mL}$ of goat anti-rat IgG (R\&D Systems) (diluted in PBS) were added to nontreated $10-\mathrm{cm}$ plastic dishes at a concentration of 10 $\mu \mathrm{g} / \mathrm{mL}$ and incubated for $30 \mathrm{~min}$ at $37^{\circ} \mathrm{C}$. Dishes were washed five times with PBS, followed by blocking with $2 \mathrm{~mL}$ of $2 \%$ BSA in PBS for $16 \mathrm{~h}$ at $4^{\circ} \mathrm{C}$. The blocking medium was then replaced with $2 \mathrm{~mL}$ of ligand solution. For this, recombinant rat Jagged 1 protein (R\&D Systems) was diluted in $2 \%$ BSA in PBS to a final concentration of 10 or $20 \mu \mathrm{g} / \mathrm{mL}$. Dishes were incubated with the Jagged 1 ligand solution for $2 \mathrm{~h}$ at $37^{\circ} \mathrm{C}$, followed by five washes with PBS. Freshly isolated dermal papilla cells from P1 wild-type mice were then seeded at a concentration of 200,000 cells per dish and cultured in DMEM (Gibco) and 10\% FBS (Sigma) for $24 \mathrm{~h}$.

For Wnt5a promoter activity assays, the mouse Wnt5a promoter and first intronic region $(3.943 \mathrm{~kb}$, spanning from -1.66 to $+2.29 \mathrm{~kb}$ relative to the transcription start site) was amplified by PCR of genomic DNA using the following primers: 5 '-CCTT CTACCCTTGAACGTTG-3' (Forward) and 5'-TTGAAGGACT GGGACTCAGA-3' (Reverse). The product of the PCR was cloned into the pGL4 vector (Promega) at the BglII/HindIII sites to generate the Wnt5a-luc reporter plasmid. For removal of the two RBP-Jk-binding sites, located at positions -1.64 and $+1.81 \mathrm{~kb}$ relative to the transcription start site, the Wnt5a-luc plasmid DNA was digested by BglII/SmaI to remove 368 base pairs (bp) of $5^{\prime}$ upstream sequence, enclosing the first site, and by BsaI/MluI, for an internal deletion of $233 \mathrm{bp}(+1.78$ to $+2.01 \mathrm{~kb})$, enclosing

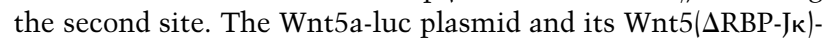
luc derivative were cotransfected into Saos-2 cells (in 12-well plates; $1 \mu \mathrm{g}$ of DNA per well) together with an expression vector for activated Notch1 ( $2 \mu \mathrm{g}$ of DNA per well) (Rangarajan et al. 2001) or empty vector control and the renilla phRL-TK reporter (Promega) for internal normalization. Cells were harvested $48 \mathrm{~h}$ after transfection, and were assayed with Dual Luciferase Reporter Assay System (Promega) according to the manufacturer's instructions. All experiments were performed in triplicate.

\section{Skin and hair follicle organ cultures}

Full-thickness back skin from mice of the indicated age and background was placed in semisolid agarose medium $(0.25 \%$ agarose [Sigma] in DMEM + 10\% FBS), with the upper surface of 
the skin exposed to the air interface. For Wnt5a treatment experiments, two halves of the same skin samples were placed in culture in separate wells, followed, after $24 \mathrm{~h}$ of adaptation to culture conditions, by transfer to fresh semisolid medium containing either Wnt5a $(200 \mathrm{ng} / \mathrm{mL})$ or BSA alone. Samples were further transferred to freshly supplemented semisolid medium $48 \mathrm{~h}$ later. Recombinant Wnt5a protein was purchased from a commercial source (R\&D Systems) and dissolved in $1 \%$ BSA-PBS to achieve $100 \mu \mathrm{g} / \mathrm{mL}$ stock solution.

For hair follicle cultures, hair follicles physically separated from the skin of $\mathrm{P0}$ mice of the indicated background were placed onto 12 wells with organotypic inserts (Millipore) $(\sim 1,000$ follicles per well), with $2 \mathrm{~mL}$ of DMEM $+10 \%$ FBS per well and $0.5 \mathrm{~mL}$ of the same added to the insert. Samples were adapted to culture conditions for $24 \mathrm{~h}$ prior to treatment with Wnt5a $(200 \mathrm{ng} / \mathrm{mL}$ final concentration) or BSA alone.

For siRNA-mediated knockdown experiments, P0 hair follicles, isolated as described above, were resuspended in HBSS (without $\mathrm{Ca}^{2+}$ and $\mathrm{Mg}^{2+}$ ) (Gibco) and transferred to six-well plates (Ultra-Low attachment microplates; Corning). About 1000 hair follicles were added per well, in $1.8 \mathrm{~mL}$ of culture medium, and kept on ice. siRNA transfection was performed with INTERFERin reagent (Polyplus) according to the manufacturer's recommendations. For each sample, $20 \mu \mathrm{L}$ of siRNAs (from $10 \mu \mathrm{M}$ stock) was added to $80 \mu \mathrm{L}$ of $5 \%$ glucose and mixed with $12 \mu \mathrm{L}$ of INTERFERin diluted into $88 \mu \mathrm{L}$ of $5 \%$ glucose by gentle vortex for $10 \mathrm{sec}$. The mix was then incubated for $10 \mathrm{~min}$ at room temperature before adding to the hair follicle HBSS suspension, with a final siRNA concentration of $100 \mathrm{nM}$. The transfected hair follicle suspension was kept for $24 \mathrm{~h}$ at $4^{\circ} \mathrm{C}$, followed by replacing HBSS with $2 \mathrm{~mL}$ of low-calcium mouse keratinocyte culture medium (Dotto et al. 1988) and culturing for $4 \mathrm{~d}$ at $34^{\circ} \mathrm{C}$ in $7.5 \%$ $\mathrm{CO}_{2}$ condition. Medium was changed after $48 \mathrm{~h}$ (by hair follicle centrifugation at $450 \mathrm{rpm}$ for $5 \mathrm{~min}$ at $4^{\circ} \mathrm{C}$ ). For Wnt5a treatment, culture medium was replaced for the last $24 \mathrm{~h}$ of the experiment with $2 \mathrm{~mL}$ of fresh culture medium containing recombinant Wnt5a (200 ng/mL final concentration) or BSA alone $(0.05 \%)$.

\section{Hair follicle reconstitution assays}

For each injection, $1 \times 10^{6}$ freshly isolated $\mathrm{CD} 133^{+}$dermal papilla cells from P1 mice (for [ColI-Cre $\times$ RBP-Jא ${ }^{10 x P / l o x P}$ ] and $\left[\right.$ RBP-J $\left.\kappa^{{ }^{\text {loxP }} / \text { loxP }}\right]$ ) and E18.5 embryos (for Wnt5a control and knockout mice) were admixed with $0.5 \times 10^{6}$ freshly isolated P1 keratinocytes from actin-EGFP transgenic mice. The mixed cells were resuspended in $50 \mu \mathrm{L}$ of DMEM $+10 \%$ FBS, and were injected at the dermal-hypodermal junction into NMRI nude mice as described previously (Zheng et al. 2005). Each mouse was injected in parallel, on the left and right flank, with keratinocytes admixed with either (ColI-Cre $\times$ RBP-Jא ${ }^{\text {loxP/loxP }}$ ) or $\left(\right.$ RBP-JK $\left.{ }^{\text {loxP/loxP }}\right)$ dermal papilla cells, or with $\mathrm{Wnt} 5 \mathrm{a}^{-/-}$versus Wnt $5 \mathrm{a}^{+/+}$dermal papilla cells. Eight to 12 mice were injected, being sacrificed at various times after injection as indicated.

\section{Full-thickness skin grafting}

Back skin of Wnt5 $\mathrm{a}^{\mathrm{tm} 1 \mathrm{Amc}} / \mathrm{tm}^{\mathrm{Am} c}$ and littermate wild-type control mice at E17.5, and (ColI-Cre $\times$ RBP-JK $\kappa^{\operatorname{loxP} / \operatorname{loxP}}$ ) and $\left(\mathrm{RBP}-\mathrm{J}^{1 \mathrm{oxP} / \mathrm{loxP}}\right)$ at P0, were cut into $5 \times 5$-mm pieces, washed thoroughly in PBS, and placed onto the recipient graft bed of nude mice (prepared by removing epidermis and superficial dermis with curved surgical scissors). To minimize individual animal variability, control and mutant skin were grafted in parallel on the left and right back flank, respectively, of each recipient mouse. Grafts were covered with a $16 \times 57-\mathrm{mm}$ wound bandage and further secured with adhesive tape. Bandage and adhesive tape were changed every day. Three days later, grafts were exposed to air until harvest.

\section{Immunofluorescence staining and confocal analysis}

The following primary antibodies were used: AE13 and AE15 (1:25; kindly provided by Dr. T.T. Sun), CD133 (1:200; eBiosciences), Cre (1:200; Novagen), cytokeratin 1 (1:500; Covance), cytokeratin 10 (1:500; Covance), cytokeratin 14 (1:1000; Covance), cytokeratin 6 (1:1000; Covance), FoxN1 (1:50; Santa Cruz Biotechnology), GFP (1:500; Abcam), Sox2 (1:50; R\&D Systems), Versican (1:200; Chemicon), and Wnt5a (1:100; R\&D Systems). The secondary antibodies were conjugated with Alexa Fluor 488 or 568 (Invitrogen). Counterstaining of nuclei was performed with DAPI.

Embryos or newborn pups were cryosectioned in sagittal direction at $20 \mu \mathrm{m}$ at the midline of the body. Sections were fixed in precooled acetone for $20 \mathrm{~min}$ at $-20^{\circ} \mathrm{C}$, permeabilized for $20 \mathrm{~min}$ in PBST (PBS with $0.1 \%$ Triton X-100), and incubated in blocking solution (PBS with 2.5\% donkey serum, $2.5 \%$ goat serum, $0.5 \%$ cold water fish gelatin, $0.5 \% \mathrm{BSA}$ ) for $60 \mathrm{~min}$. Incubation with primary antibodies was for either $2 \mathrm{~h}$ at room temperature or $12 \mathrm{~h}$ at $4^{\circ} \mathrm{C}$. For immunostaining of Cre and CD133, enzymatically dissociated total dermal cells were fixed in $4 \%$ PFA for $20 \mathrm{~min}$ on ice and then stained with the above protocol.

Images were acquired with a Zeiss LSM510 meta laserscanning microscope (Carl Zeiss MicroImaging). For histological sections and whole-mount samples, $Z$ stacks $(1 \mu \mathrm{m})$ of six to eight and 20 planes, respectively, were acquired.

\section{Quantitative real-time RT-PCR, immunodetection, and ChIP techniques}

Conditions for real-time RT-PCR and immunoblotting were as described previously (Lefort et al. 2007). Immunoblotting was performed with the following antibodies: Wnt5a (R\&D Systems), Fgf10 (Santa Cruz Biotechnology), Noggin (Santa Cruz Biotechnology), and $\beta$-actin (Santa Cruz Biotechnology).

ChIP assays were performed as described previously (Lefort et al. 2007). The list of gene-specific primers is provided in Supplemental Table S1.

\section{Acknowledgments}

We thank Dr. T. Honjo (Kyoto University, Kyoto, Japan) for generously providing the RBP-J $\kappa^{\text {loxP/loxP }}$ mice, Dr. M. Okabe (Osaka University, Suita, Japan) for the C57BL/6-Tg(Act-EGFP) transgenic strain, Dr. T.T. Sun (New York University, NY, USA) for his gift of antibodies, Dr. D.M. Prowse (Cancer Research UK, London, UK) for the pBabepuroFoxN1-ER construct, Dr. U. Just (Christian-Albrechts-University of Kiel, Germany) for the rNERT-neo and rneo plasmids, and Dr. C. Missero for careful reading of the manuscript. This work was supported by grants from the Swiss National Foundation, Oncosuisse (Grant 0236102-2009), the European Union (Epistem, Sixth Framework Program, LSHB-CT-2005-019067), and the NIH (Grants AR39190 and AR054856) to G.P.D.

\section{References}

Balciunaite G, Keller MP, Balciunaite E, Piali L, Zuklys S, Mathieu YD, Gill J, Boyd R, Sussman DJ, Hollander GA. 2002. Wnt glycoproteins regulate the expression of FoxN1, the gene defective in nude mice. Nat Immunol 3: 11021108 .

Baxter RM, Brissette JL. 2002. Role of the nude gene in epithelial terminal differentiation. J Invest Dermatol 118: 303-309. 
Berton TR, Wang XJ, Zhou Z, Kellendonk C, Schutz G, Tsai S, Roop DR. 2000. Characterization of an inducible, epidermalspecific knockout system: Differential expression of lacZ in different Cre reporter mouse strains. Genesis 26: 160-161.

Blanpain C, Lowry WE, Pasolli HA, Fuchs E. 2006. Canonical notch signaling functions as a commitment switch in the epidermal lineage. Genes Dev 20: 3022-3035.

Blumenthal A, Ehlers S, Lauber J, Buer J, Lange C, Goldmann T, Heine H, Brandt E, Reiling N. 2006. The Wingless homolog WNT5A and its receptor Frizzled-5 regulate inflammatory responses of human mononuclear cells induced by microbial stimulation. Blood 108: 965-973.

Botchkarev VA, Paus R. 2003. Molecular biology of hair morphogenesis: Development and cycling. I Exp Zoolog B Mol Dev Evol 298: 164-180.

Bray SJ. 2006. Notch signalling: A simple pathway becomes complex. Nat Rev Mol Cell Biol 7: 678-689.

Demehri S, Kopan R. 2009. Notch signaling in bulge stem cells is not required for selection of hair follicle fate. Development 136: $891-896$.

Dotto GP. 2008. Notch tumor suppressor function. Oncogene 27: $5115-5123$.

Dotto GP, Weinberg RA, Ariza A. 1988. Malignant transformation of mouse primary keratinocytes by Harvey sarcoma virus and its modulation by surrounding normal cells. Proc Natl Acad Sci 85: 6389-6393.

Driskell RR, Giangreco A, Jensen KB, Mulder KW, Watt FM. 2009. Sox2-positive dermal papilla cells specify hair follicle type in mammalian epidermis. Development 136: 2815-2823.

Estrach S, Ambler CA, Lo Celso C, Hozumi K, Watt FM. 2006. Jagged 1 is a $\beta$-catenin target gene required for ectopic hair follicle formation in adult epidermis. Development 133: 4427-4438.

Florin L, Alter H, Grone HJ, Szabowski A, Schutz G, Angel P. 2004. Cre recombinase-mediated gene targeting of mesenchymal cells. Genesis 38: 139-144.

Han $\mathrm{H}$, Tanigaki $\mathrm{K}$, Yamamoto N, Kuroda K, Yoshimoto M, Nakahata T, Ikuta K, Honjo T. 2002. Inducible gene knockout of transcription factor recombination signal binding protein- $\mathrm{J}$ reveals its essential role in $\mathrm{T}$ versus $\mathrm{B}$ lineage decision. Int Immunol 14: 637-645.

Hurlbut GD, Kankel MW, Lake RJ, Artavanis-Tsakonas S. 2007. Crossing paths with Notch in the hyper-network. Curr Opin Cell Biol 19: 166-175.

Janes SM, Ofstad TA, Campbell DH, Watt FM, Prowse DM. 2004. Transient activation of FOXN1 in keratinocytes induces a transcriptional programme that promotes terminal differentiation: Contrasting roles of FOXN1 and Akt. J Cell Sci 117: 4157-4168.

Johns SA, Soullier S, Rashbass P, Cunliffe VT. 2005. Foxn1 is required for tissue assembly and desmosomal cadherin expression in the hair shaft. Dev Dyn 232: 1062-1068.

Kopan R, Ilagan MX. 2009. The canonical Notch signaling pathway: Unfolding the activation mechanism. Cell 137: 216-233.

Lee J, Basak JM, Demehri S, Kopan R. 2007. Bi-compartmental communication contributes to the opposite proliferative behavior of Notch1-deficient hair follicle and epidermal keratinocytes. Development 134: 2795-2806.

Lefort K, Mandinova A, Ostano P, Kolev V, Calpini V, Kolfschoten I, Devgan V, Lieb J, Raffoul W, Hohl D, et al. 2007. Notch1 is a p53 target gene involved in human keratinocyte tumor suppression through negative regulation of ROCK1/2 and MRCK $\alpha$ kinases. Genes Dev 21: 562-577.

Lynch MH, O'Guin WM, Hardy C, Mak L, Sun TT. 1986. Acidic and basic hair/nail ('hard') keratins: Their colocalization in upper cortical and cuticle cells of the human hair follicle and their relationship to 'soft' keratins. J Cell Biol 103: 25932606.

Mandinova A, Kolev V, Neel V, Hu B, Stonely W, Lieb J, Wu X, Colli C, Han R, Pazin M, et al. 2009. A positive FGFR3/ FOXN1 feedback loop underlies benign skin keratosis versus squamous cell carcinoma formation in humans. J Clin Invest 119: $3127-3137$.

Mecklenburg L, Nakamura M, Sundberg JP, Paus R. 2001. The nude mouse skin phenotype: The role of Foxn1 in hair follicle development and cycling. Exp Mol Pathol 71: 171-178.

Mecklenburg L, Tychsen B, Paus R. 2005. Learning from nudity: Lessons from the nude phenotype. Exp Dermatol 14: 797810.

Mikels AJ, Nusse R. 2006. Purified Wnt5a protein activates or inhibits $\beta$-catenin-TCF signaling depending on receptor context. PLoS Biol 4: e115. doi: 10.1371/journal.pbio.0040115.

Moriyama M, Osawa M, Mak SS, Ohtsuka T, Yamamoto N, Han H, Delmas V, Kageyama R, Beermann F, Larue L, et al. 2006. Notch signaling via Hes1 transcription factor maintains survival of melanoblasts and melanocyte stem cells. J Cell Biol 173: 333-339.

Nakamura $Y$, Ichinohe M, Hirata M, Matsuura H, Fujiwara T, Igarashi T, Nakahara $M$, Yamaguchi $H$, Yasugi S, Takenawa T, et al. 2008. Phospholipase C- $\delta 1$ is an essential molecule downstream of Foxn1, the gene responsible for the nude mutation, in normal hair development. FASEB J 22: 841-849.

Nomachi A, Nishita M, Inaba D, Enomoto M, Hamasaki M, Minami Y. 2008. Receptor tyrosine kinase Ror2 mediates Wnt5a-induced polarized cell migration by activating c-Jun N-terminal kinase via actin-binding protein filamin A. J Biol Chem 283: 27973-27981.

O'Connell MP, Fiori JL, Xu M, Carter AD, Frank BP, Camilli TC, French AD, Dissanayake SK, Indig FE, Bernier M, et al. 2010. The orphan tyrosine kinase receptor, ROR2, mediates Wnt5A signaling in metastatic melanoma. Oncogene 29: 34-44.

Oishi I, Takeuchi S, Hashimoto R, Nagabukuro A, Ueda T, Liu ZJ, Hatta T, Akira S, Matsuda Y, Yamamura H, et al. 1999. Spatio-temporally regulated expression of receptor tyrosine kinases, mRor1, mRor2, during mouse development: Implications in development and function of the nervous system. Genes Cells 4: 41-56.

Okabe M, Ikawa M, Kominami K, Nakanishi T, Nishimune Y. 1997. 'Green mice' as a source of ubiquitous green cells. FEBS Lett 407: 313-319.

Okuyama R, Nguyen BC, Talora C, Ogawa E, di Vignano AT, Lioumi M, Chiorino G, Tagami H, Woo M, Dotto GP. 2004. High commitment of embryonic keratinocytes to terminal differentiation through a Notch1-caspase 3 regulatory mechanism. Dev Cell 6: 551-562.

Pan Y, Lin MH, Tian X, Cheng HT, Gridley T, Shen J, Kopan R. 2004. $\gamma$-Secretase functions through Notch signaling to maintain skin appendages but is not required for their patterning or initial morphogenesis. Dev Cell 7: 731-743.

Pukrop T, Klemm F, Hagemann T, Gradl D, Schulz M, Siemes S, Trumper L, Binder C. 2006. Wnt 5a signaling is critical for macrophage-induced invasion of breast cancer cell lines. Proc Natl Acad Sci 103: 5454-5459.

Rangarajan A, Talora C, Okuyama R, Nicolas M, Mammucari C, Oh H, Aster JC, Krishna S, Metzger D, Chambon P, et al. 2001. Notch signaling is a direct determinant of keratinocyte growth arrest and entry into differentiation. $E M B O J \mathbf{2 0}$ 3427-3436.

Reddy S, Andl T, Bagasra A, Lu MM, Epstein DJ, Morrisey EE, Millar SE. 2001. Characterization of Wnt gene expression in developing and postnatal hair follicles and identification of 
Hu et al.

Wnt5a as a target of Sonic hedgehog in hair follicle morphogenesis. Mech Dev 107: 69-82.

Rendl M, Lewis L, Fuchs E. 2005. Molecular dissection of mesenchymal-epithelial interactions in the hair follicle. PLOS Biol 3: e331. doi: 10.1371/journal.pbio.0030331.

Rinn JL, Wang JK, Allen N, Brugmann SA, Mikels AJ, Liu H, Ridky TW, Stadler HS, Nusse R, Helms JA, et al. 2008. A dermal HOX transcriptional program regulates site-specific epidermal fate. Genes Dev 22: 303-307.

Schroeder T, Just U. 2000. Notch signalling via RBP-J promotes myeloid differentiation. EMBO J 19: 2558-2568.

Soriano P. 1999. Generalized lacZ expression with the ROSA26 Cre reporter strain. Nat Genet 21: 70-71.

Szabowski A, Maas-Szabowski N, Andrecht S, Kolbus A, Schorpp-Kistner M, Fusenig NE, Angel P. 2000. c-Jun and JunB antagonistically control cytokine-regulated mesenchymal-epidermal interaction in skin. Cell 103: 745-755.

Takeuchi S, Takeda K, Oishi I, Nomi M, Ikeya M, Itoh K, Tamura S, Ueda T, Hatta T, Otani H, et al. 2000. Mouse Ror2 receptor tyrosine kinase is required for the heart development and limb formation. Genes Cells 5: 71-78.

van Amerongen R, Mikels A, Nusse R. 2008. Alternative wnt signaling is initiated by distinct receptors. Sci Signal 1: re9. doi: $10.1126 /$ scisignal.135re9.

Wang Y, Nathans J. 2007. Tissue/planar cell polarity in vertebrates: New insights and new questions. Development 134: 647-658.

Watt FM, Estrach S, Ambler CA. 2008. Epidermal Notch signalling: Differentiation, cancer and adhesion. Curr Opin Cell Biol 20: 171-179.

Weiner L, Han R, Scicchitano BM, Li J, Hasegawa K, Grossi M, Lee D, Brissette JL. 2007. Dedicated epithelial recipient cells determine pigmentation patterns. Cell 130: 932-942.

Yamaguchi TP, Bradley A, McMahon AP, Jones S. 1999. A Wnt5a pathway underlies outgrowth of multiple structures in the vertebrate embryo. Development 126: 1211-1223.

Yamamoto N, Tanigaki K, Han H, Hiai H, Honjo T. 2003. Notch/RBP-J signaling regulates epidermis/hair fate determination of hair follicular stem cells. Curr Biol 13: 333-338.

Yamamoto S, Nishimura O, Misaki K, Nishita M, Minami Y, Yonemura S, Tarui H, Sasaki H. 2008. Cthrc1 selectively activates the planar cell polarity pathway of Wnt signaling by stabilizing the Wnt-receptor complex. Dev Cell 15: 23-36.

Yang Y, Topol L, Lee H, Wu J. 2003. Wnt5a and Wnt5b exhibit distinct activities in coordinating chondrocyte proliferation and differentiation. Development 130: 1003-1015.

Zheng Y, Du X, Wang W, Boucher M, Parimoo S, Stenn K. 2005. Organogenesis from dissociated cells: Generation of mature cycling hair follicles from skin-derived cells. I Invest Dermatol 124: 867-876. 


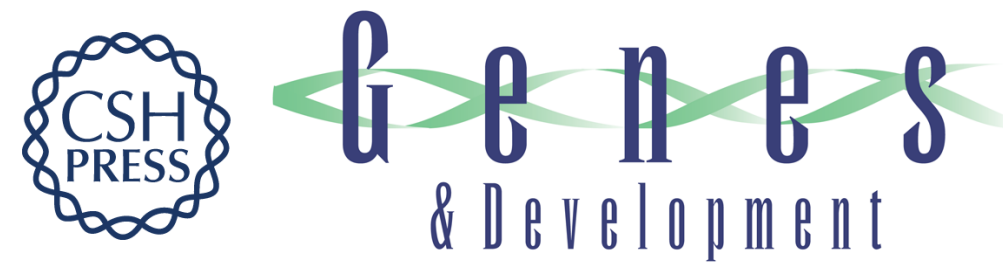

\section{Control of hair follicle cell fate by underlying mesenchyme through a CSL-Wnt5a-FoxN1 regulatory axis}

Bing $\mathrm{Hu}$, Karine Lefort, Wenying Qiu, et al.

Genes Dev. 2010, 24:

Access the most recent version at doi:10.1101/gad.1886910

Supplemental
Material http://genesdev.cshlp.org/content/suppl/2010/07/12/24.14.1519.DC1

References This article cites 51 articles, 20 of which can be accessed free at:

http://genesdev.cshlp.org/content/24/14/1519.full.html\#ref-list-1

License

Email Alerting

Receive free email alerts when new articles cite this article - sign up in the box at the top

Service

right corner of the article or click here.

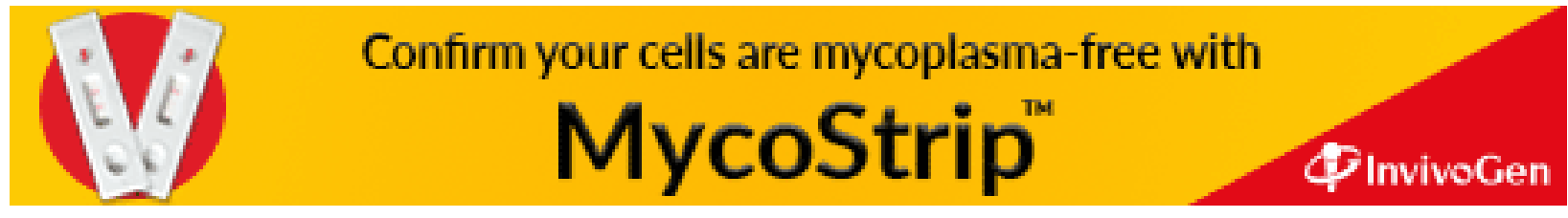

